\title{
Direito Natural e Ordem Constitucional Brasileira:
} As Origens do 'Neoconstitucioniilismo' no Jusnaturalismo Moderno

Marcos Paulo Fernandes de Araíjo *

\begin{abstract}
RESUMO: Este artigo investiga a relação entre o Direito Natural e a ordem constitucional brasileira, marcada pelo predomínio do neoconstitucionalismo. Tomando como ponto de partida do Direito Natural moderno a doutrina de Guilherme de Ockham, avançando pelas de Hobbes e Locke e chegando até Sieyès, procura-se demonstrar como o neoconstitucionalismo, longe de constituir algo de novo é apenas um novo estágio de desenvolvimento dessas doutrinas que são, já em sua raiz, nominalistas e antimetafísicas, não constituindo tampouco uma superação do positivismo kelseniano, já que, como este, também é voluntarista em suas bases. Ao final, propõe-se um retorno à metafísica tomista do ato de ser intensivo como fundamento da construção de uma ordem jurídica renovada.
\end{abstract}

Palavras-Chave: Constituição Brasileira de 1988; Direito Natural; Constitucionalismo (Neo); Crítica; Filosofia do Ser.

\section{Contexto histórico}

$\mathrm{Na}$ primeira metade do século XX, coube à humanidade deparar-se com problemas de uma natureza e de uma magnitude incomparáveis com os quais já havia sido confrontada até então. Os acontecimentos abomináveis e ruinosos que caracterizaram as duas grandes guerras, e a ascensão dos totalitarismos - um dos quais havia sido, felizmente, derrotado, embora deixando pelo caminho um rastro de destruição e crueldade, com morticínio de milhões -, causaram na humanidade a incontrastável impressão de que havia algo profundamente errado no modo como os homens vinham conduzindo suas vidas e, sobretudo, suas instituições.

Era imperioso sair no encalço dos culpados. No campo da psicologia, Viktor Frankl, um sobrevivente dos campos de concentração, já apontara que os extermínios em massa haviam nascido nas escrivaninhas dos pensa-

* Bacharel e Mestre em Direito, Universidade do Estado do Rio de Janeiro (UERJ), Doutor em Direito, Universidade Federal do Rio Grande do Sul (UFRGS).. 
dores niilistas. A parcela de culpa no campo do pensamento jurídico ameaçava recair principalmente sobre o Positivismo Jurídico. Um de seus mais consagrados expositores, Gustav Radbruch, não tardou a proferir o j(e m)'accuse, no seu célebre mea culpa intitulado Cinco minutos de Filosofia do Direito ${ }^{1}$, dirigido em forma de circular aos alunos da Universidade de Heidelberg, instando os juristas a um volver de olhos sobre a consideração dos valores.

A convicção da humanidade no mito do progresso ("um dos artigos mais [...] complexos encontrados no mercado de superstições de nosso tempo"2, como disse Hannah Arendt) tão fomentado pela atmosfera gerada em torno ao Positivismo, parecia estar, em meio aos escombros fumegantes dos metais incinerados pelo fogo consumidor do seu ciumento "deus", severamente abalada. Era necessário voltar atrás. No entanto, essa mesma fumaça levantada pelo incêndio ritual do Positivismo em homenagem ao seu objeto de culto não apenas parecia dificultar esse necessário olhar retrospectivo, como continuava a inebriar os homens, a ponto de lhes debilitar a vontade requerida pela hercúlea tarefa que significava abandonar o antigo e nefasto ídolo.

Era necessário voltar atrás, ma non troppo. Afinal, a crença no Progresso estava abalada; não, porém, desmantelada. Com efeito, o ídolo queimado parecia ressurgir das próprias cinzas. Recorrer à "Idade das Trevas" em busca de inspiração não era uma opção. Diante do fragoroso fracasso do seu cavalo no grande páreo da corrida das ideias humanas, os aderentes do mito do Progresso não se acanharam, e a meta, que havia sido deixada em aberto, agora era dobrada. Neste contexto, a opção por um expediente gestado na ambiência do "Século das Luzes" foi a resposta encontrada pelos homens do século dos totalitarismos e dos genocídios para a solução dos seus problemas. Era necessário, então, como outrora ${ }^{3}$, declarar os Direitos do Ho-

${ }^{1}$ Gustav Radbruch, "Cinco minutos de filosofia do direito", Publicaçoes da Advocacia Geral da União-AGU, 17 (2012): 261-263. Disponível em https://seer.agu.gov.br/index.php/ EAGU/article/view/1620. Acesso em 18 jun. 2020.

${ }^{2}$ Hannah Arendt, Sobre a Violência (Rio de Janeiro: Relume Dumará, 2001), 29.

3 Uma breve inspeção é o suficiente para verificar as semelhanças entre a Declaração de 1789 e a de 1948. Basta a simples mensagem preambular: "Os representantes do povo francês" iniciam a primeira "considerando que a ignorância, o esquecimento ou desprezo dos direitos do homem são as únicas causas dos infortúnios públicos e da corrupção dos governos", ao passo que a Assembleia das Nações Unidas inicia a segunda

"considerando que a desconsideração e o desprezo pelos direitos do homem conduziram a atos de barbárie". Cf. Assemblée Nationale. Déclaration des Droits de l'Homme et du Citoyen de 1789. (Paris: Légifrance). Disponível em https://www.legifrance.gouv.fr/Droitfrancais/Constitution/Declaration-des-Droits-de-l-Homme-et-du-Citoyen-de-1789. Acesso em 19 jul. 2020; Universal Declaration of Human Rights. (United Nations, 1948). Disponível em https://www.un.org/en/universal-declaration-human-rights/. Acesso em 19 jul. 2020. 
mem4. Buscar um acordo "prático", na ausência de um teórico 5 (como se fosse possível sustentar tal situação).

O efeito da reabilitação do discurso permeado de valores e da nova Declaração de Direitos Humanos sobre os governos nacionais e suas constituições não se fez tardar. É na esteira desse "retorno aos valores como caminho para a superação dos positivismos"" e da "reconstrução dos direitos humanos"7 que se insere o processo constituinte e constitucional no Brasil, após os mais de vinte anos de regime militar.

Neste sentido, a Constituição Brasileira de 1988 é, de certo modo, um estágio ulterior e tardio na incorporação de uma série de discursos a ordens jurídicas nacionais. Ela veio a refletir, quarenta anos após a Declaração da ONU, aquele mesmo conjunto de ideias sobre direito e política que havia sido propagado a partir do pós-II Guerra, ecoando um paradigma acerca dos Direitos Humanos já encontradiço, àquela altura, em inúmeras constituições europeias, como a italiana (1947), a alemã (1956), a portuguesa (1976) e a espanhola (1978). Ela representava, portanto, o nosso passaporte para a Era dos Direitos declarada por Bobbio, que se importava menos ainda que Maritain ${ }^{8}$ com a justificação e a compreensão dos Direitos Humanos, fazendo, porém, de sua defesa um imperativo9.

\section{O Neoconstitucionalismo}

No entanto, enganar-se-ia quem se pusesse a buscar apenas no Direito Constitucional europeu do pós-II Guerra as origens da atual ordem constitucional brasileira (supondo, é claro, ser possível chamá-la por esse nome). É necessário olhar também para a América, para que se possa atinar com a origem de suas peculiaridades. Parte destas, é verdade, já vinha sendo incorporada de maneira indireta, por ocasião da própria inspiração que a Suprema Corte dos Estados Unidos havia dado ao estabelecimento dos tribunais constitucionais europeus. Por outro lado, é preciso não esquecer o

${ }^{4}$ Pierre Manent, Cours Familier de Philosophie Politique (Paris: Gallimard, 2016), 163-181.

5 Jacques Maritain, Les droits de l'homme. (Paris: Desclée de Brouwer, 1989), 117-118.

${ }^{6}$ Cf. Ricardo Lobo Torres. Tratado de Direito Constitucional, Financeiro e Tributário: valores e princípios constitucionais tributários. Apud Luís Roberto Barroso. "Neoconstitucionalismo e constitucionalização do direito: o triunfo tardio do direito constitucional no Bra-

sil" (Publicado no site do autor, 2005). 6, n. 9. Disponível em: http://

www.luisrobertobarroso.com.br/wp-content/uploads/2017/09/

neoconstitucionalismo_e_constitucionalizacao_do_direito_pt.pdf. Acesso em 17 jun.

2020, originalmente publicado em Revista de Direito Administrativo, Rio de Janeiro, 240,

(abr./jun. 2005): 1-42.

${ }^{7}$ Celso Lafer, A reconstrução dos Direitos Humanos (São Paulo: Companhia das Letras, 1991).

8 Cf. acima, n. 5.

${ }^{9}$ Norberto Bobbio, A Era dos Direitos (Rio de Janeiro: Campus, 2002), 37. 
papel desempenhado pelo Civil Rights Movement, posterior ao início do movimento das constituições europeias do pós-II Guerra, sobre o Direito Constitucional brasileiro.

O Civil Rights Movement consistiu num grande esforço protagonizado por advogados e ativistas dos Estados Unidos, cujo principal objetivo era, ao menos inicialmente, reverter a injustiça estrutural que caracterizava as instituições políticas dos estados do Sul do país, os mesmos que haviam saído derrotados da Guerra de Secessão, e que, após a morte de Lincoln, viram a escravidão ser abolida em seus territórios. Tal injustiça consistia na aplicação de uma doutrina intitulada separate, but equal, estabelecida no caso Plessy v. Ferguson, ${ }^{10}$ que foi revertida ao longo de uma série de julgamentos da Suprema Corte (cuja decisão favorável ao escravagismo em Dred Scott vs. Sandford havia servido de estopim para a eclosão da referida guerra ${ }^{11}$ ), dentre os quais os mais famosos são justamente Brown vs. Board of Education e Cooper vs. Aaron ${ }^{12}$, e não por via da ação legislativa democrática, algo que seria impossível aos negros, ao menos no curto prazo.

Contudo, após o sucesso obtido pelo movimento no desmantelamento das instituições raciais estruturalmente injustas, e em parte devido a ele, mas, por outro lado, também influenciado pelo discurso marxista da Escola de Frankfurt, o Civil Rights Movement acabou se transformando em um multitudinário, persistente e caótico esforço de instrumentalização das cortes com o propósito de promover determinadas causas políticas por via do ativismo judicial. Neste sentido, como narra a atual presidente da Comissão para Direitos Inalienáveis dos Estados Unidos, e ex-embaixatriz dos Estados Unidos no Vaticano, a professora de Harvard Mary Ann Glendon:

Em um breve espaço de tempo, pessoas e organizações dedicadas a causas sociais e outras conexas - como a prevenção do abuso e negligência de crianças, a melhoria no tratamento dos mental e fisicamente deficientes, a eliminação da discriminação baseada em estilos de vida, a proteção de consumidores contra práticas abusivas, o combate à crueldade contra animais e o cuidado do meio ambiente - começaram a articular suas demandas em termos de direitos. ${ }^{13}$

Seria leviano menosprezar o influxo que essa corrente de pensamento exerceu no pensamento constitucional brasileiro. Afinal, poucos discorda-

\footnotetext{
${ }^{10}$ Ronald Dworkin, O Direito da Liberdade: a leitura moral da Constituição norte-americana. 2. ed. (São Paulo: WMF Martins Fontes, 2019), 203.

11 Cf. Robert P. George, Conscience and its enemies: confronting the dogmas of secular liberalism. (Willmington, Delaware: ISI Books, 2013), 45-46.

12 Cf. George, Conscience and its enemies, 42-43.

${ }_{13}$ Mary Ann Glendon, Rights Talk: the impoverishment of political discourse (New York: The Free Press, c1991), 7.
} 
riam da prevalência, neste, daquela linha de pensamento que, amplamente baseada nos postulados defendidos pelos politólogos do espectro liberall4 norte-americano, como Rawls e Dworkin, acabou por receber a alcunha, da parte de seus próprios difusores, de 'neoconstituciona-lismo'15.

É em meio a este cenário de incertezas que o corifeu dessa corrente, o atual ministro do Supremo Tribunal Federal, Luis Roberto Barroso, a despeito de situá-la historicamente no quadro de uma "superação histórica do jusnaturalismo"16 - que, em sua época, isto é, os séculos XVII e XVIII, "foi o combustível das revoluções liberais e chegou ao apogeu com as Constituições escritas"17-, ao incluí-la entre aquelas doutrinas que receberam genericamente o rótulo de "pós-positivismo", ressalva que "imerso nos acontecimentos, não pode o intérprete beneficiar-se do distanciamento crítico em relação ao fenômeno que lhe cabe analisar", terminando por admitir, diante do aparente embaraço com a situação, que talvez "esta seja uma boa explicação para o recurso recorrente aos prefixos pós e neo:
pós-modernidade, pós-positivismo, neoliberalismo, neocons- titucionalismo. Sabe-se que veio depois e que tem a pretensão de ser novo. Mas ainda não se sabe bem o que é. Tudo é ain- da incerto. Pode ser avanço. Pode ser uma volta ao passado. Pode ser apenas um movimento circular, uma dessas guinadas de 360 graus. ${ }^{18}$

Em outro artigo de sua lavra, publicado mais recentemente, embora Barroso tenha atribuído já um valor inequivocamente positivo à doutrina que advoga e que conseguiu emplacar no STF, cujo papel seria fazer avançar a roda da História ${ }^{19}$, a alusão ao ambiente intelectual engendrado no século "das luzes" não apenas é mantida, mas reforçada, passando a figurar no próprio título: Contramajoritário, Representativo e Iluminista ${ }^{20}$.

\footnotetext{
${ }^{14}$ Leia-se: esquerdista.

15 A primeira aparição do termo parece ter ocorrido na obra de Miguel Carbonell, Neoconstitucionalismo(s). (Madrid: Trotta, 2003), citado em Luís Roberto Barroso, Neoconstitucionalismo e constitucionalização do direito: o triunfo tardio do direito constitucional no Brasil (Publicado no site do autor, 2005). Disponível em http://www.luisrobertobarroso.com.br/wp-content/ uploads/2017/09/neoconstitucionalismo_e_constitucionalizacao_do_direito_pt.pdf.

Acesso em 07 jun. 2020, 16, n. 31; 18, n. 32; 21 n. 43 e 22, n. 44.

${ }^{16}$ Ibid., 6.

17 Ibid., 5 .

18 Ibid., 2.

${ }^{19}$ A este respeito, cf. Henrique Montagner Fernandes, “' $O$ nosso papel é empurrar a História (...) a serviço da causa da humanidade’: construção, reprodução e reação à doutrina neoconstitucionalista no Brasil"' (Tese de Doutorado em Direito, Universidade Federal do Rio Grande do Sul, 2020).

${ }^{20}$ Luis Roberto Barroso, "Contramajoritário, Representativo e Iluminista: Os papeis dos tribunais constitucionais nas democracias contemporâneas", Direito e Práxis, v. 9, n. 4, (2018): 2171-2228.
} 
Outros autores afins a esta corrente de pensamento representada por Rawls e Dworkin, como Jonathan Israel ${ }^{21}$ e José Reinaldo de Lima Lopes $^{22}$, tampouco hesitam em situar a origem do movimento mais amplo em que o neonconstitucionalismo se insere no Iluminismo. Entre aqueles que criticam tal movimento, não faltam autores a notá-lo: na França, Chantal Delsol $^{23}$, e Pierre Manent ${ }^{24}$; no mundo anglo-saxão, Alasdair MacIntyre ${ }^{25}$; na Itália, Danilo Castellano ${ }^{26}$ e, na América Latina, Carlos Ignacio Massini Correas $^{27}$ e Luis Fernando Barzotto ${ }^{28}$.

Dadas estas considerações, é possível reconhecer preliminarmente uma relação indireta entre o neoconstitucionalismo, corrente prevalente na interpretação da Constituição Brasileira de 1988, em sua reivindicação de filiação ao Iluminismo, e a doutrina do Direito Natural Moderno - origem filosófica do primeiro constitucionalismo - por ao menos duas vias: uma é a senda que se origina no Direito Constitucional europeu, que se abeberou da Declaração Universal dos Direitos Humanos de 1948, cuja semelhança com a Declaração de Direitos do Homem e do Cidadão proclamada pela Assembleia Nacional durante a Revolução Francesa, de 1789, é inegável; outra oriunda do Civil Rights Movement norte-americano, iniciado no fim dos anos 50, e que parece ser, das duas, a mais influente.

Por isto, a concepção do Direito Natural Moderno que se passará a expor se concentrará especificamente nas correntes mais determinantes para a emergência desse discurso sobre os direitos. Ela se inicia com o despertar do individualismo moderno, no século XIV, na doutrina de Guilherme de Ockham, mas continua a se desenvolver, mais especificamente no mundo intelectual anglo-saxão, no pensamento de Thomas Hobbes (15881679) e de John Locke (1632-1704), autores apontados por Glendon como

21 Jonathan Israel, Democratic Enlightment: Philosophy, Revolution and Human Rights 1750-1790 (Oxford: Oxford University Press, 2013), 33 et passim.

22 José Reinaldo de Lima Lopes; Oscar Vilhena Vieira, "Religião e Direitos Humanos", Opinião, O Estado de São Paulo (São Paulo, SP) 22 abr. 2013.

${ }^{23}$ Cf. a obra (totalmente dedicada ao assunto) de Chantal Delsol, La haîne du monde: totalitaristmes et postmodernité (Paris: Du Cerf, 2016), 126 et passim.

24 Pierre Manent, La loi naturelle et les droits de l'homme (Paris: PUF, 2018), 53.

25 Alasdair MacIntyre, Depois da Virtude, trad. Jussara Simões (São Carlos: EDUSC, 2001), 126-130.

${ }^{26}$ Danilo Castellano, "El problema de la Constitución y la Ideología Constitucionalista", Revista Verbo 513-514 (2013): 181-202, p. 199 e "Constitución y Constitucionalismo", Revista Verbo 505-506 (2012): 357-364, p. 361.

${ }^{27}$ Carlos Ignacio Massini Correas, Filosofía del Derecho: Tomo I - El Derecho, los Derechos Humanos y el Derecho Natural. (Buenos Aires: Lexis Nexis Argentina, 2005), 283-286.

${ }^{28}$ Luis Fernando Barzotto, Teoria do Direito (Porto Alegre: Livraria do Advogado, 2017), $22-25$. 
estabelecedores das premissas teóricas em que passou a se assentar o sistema jurídico norte-americano. ${ }^{29}$

\section{O Direito Natural dos Antigos comparado àquele dos Modernos}

\subsection{O nascimento do Direito Natural Moderno em Ockham}

Conforme aludido, as linhas mestras que caracterizam o jusnaturalismo moderno do século XVII já se encontravam definidas desde um momento muito anterior. Mais especificamente, desde o século XIV, quando um franciscano chamado Guilherme de Ockham desafiou o mundo com uma nova forma de pensar, que logo foi cognominada de via modernorum. A esta altura do campeonato, o leitor pode estar se indagando sobre a conveniência de ir tão longe na investigação dos fatos. No entanto, toda busca pelos fundamentos encerra uma promessa: sua descoberta. E a luz que ela proporciona costuma ser recompensadora.

\subsubsection{Contexto histórico: as condenações à doutrina de S. Tomás e a querela da pobre- za franciscana}

Contudo, antes de se chegar a Ockham, faz-se necessário dar ainda um passo atrás. É preciso fitar o século XIII. Nele, mais especificamente, a 8 de março de 1274, o dominicano que mudara a história da filosofia e da teologia com sua impressionante síntese entre fé e razão, e que um dia viria a ser considerado Doutor Comum da Igreja, exalava seu último suspiro. A aprovação à obra de Tomás de Aquino, porém, àquela época, ainda estava longe de ser uma unanimidade. Muito pelo contrário: logo após a sua morte, deparou-se com encarniçadas oposições. No dia 8 de março de 1277 (data que alguns consideraram alusiva), o arcebispo e chanceler da Universidade de Paris, Étienne Tempier, assessorado por uma comissão de teólogos, lançou uma condenação a 219 teses consideradas heterodoxas em matéria de teologia e filosofia, dentre as quais se incluíam algumas nitidamente defendidas pelo Aquinate.

No entanto, talvez mais decisiva ainda do que ela tenha sido a condenação lançada apenas 10 dias depois, do outro lado do Canal da Mancha, pelo reitor da Universidade de Oxford e arcebispo de Canterbury, Robert Kilwardby: em primeiro lugar, porque este também era um dominicano; em segundo, porque as condenações atingiam um ponto central na doutri-

${ }^{29}$ Glendon, Rights Talk, 13. 
na do Aquinate, o da unicidade da forma substancial; em terceiro, porque tal quadro foi ainda agravado quando John Peckham, um Franciscano, sucedeu a Kilwardby, estendendo a condenação a outras teses de Tomás, em 1284. Desde então, não apenas Oxford, mas sobretudo sua província franciscana, acabaram por se consolidar como o principal foco da oposição à síntese tomista entre fé e razão. Será nessa atmosfera que se desenvolverá a formação intelectual daquele que ficará conhecido como o iniciador da via modernorum: Guilherme de Ockham. ${ }^{30}$

Também a terceira década do século seguinte foi marcada por acontecimentos de enorme relevância. Um deles foi a tardia reabilitação de Tomás de Aquino, com sua canonização em 1323 pelo Papa João XXII, e o levantamento da condenação a suas teses na Universidade de Paris em 1325. ${ }^{31} \mathrm{O}$ outro foi a intensificação da querela franciscana da pobreza, com a publicação da bula $A d$ Conditorem Canonum.

Mediante tal documento, o pontífice estabelecia, em contrariedade à bula Exiit qui Seminat, do seu antecessor, Nicolau III, que os bens habitualmente à disposição dos franciscanos não eram propriedade da Santa Sé, mas da própria ordem. Isto foi ocasião de revolta por parte do então geral dela, Miguel de Cesena, que iniciaria, logo a seguir, uma controvérsia de longa duração com João XXII em torno à questão, sendo apoiado pela ala mais radical de sua ordem, aquela dos Fraticelli, cognominados Espirituais. ${ }^{32}$

Após as bulas Quia quorundam e Quum inter nonnullos, lançadas no transcorrer dos dois anos seguintes, e da resposta de Miguel, que publicou um panfleto declarando heréticas várias teses de João XXII, este lançou uma bula de condenação dirigida especialmente àquele (Quia vir reprobus). Foi justamente em resposta a essa bula que que ocorreu a primeira intervenção do já mencionado Ockham nessa disputa com o papado, na qual viria a exercer o protagonismo.

Esse frade franciscano havia se revelado, desde o início de sua trajetória acadêmica, uma figura controversa. Jamais obtivera sequer o grau de mestre em Teologia, que lhe havia sido negado por parte do reitor de Oxford, John Lutterell, devido ao caráter temerário de algumas suas doutri-

\footnotetext{
${ }^{30}$ Cf. Pasquale Porro, Tomás de Aquino: perfil histórico-filosófico (São Paulo: Loyola, 2014), 341 et passim.

31 As condenações em Paris, contudo, apenas seriam levantadas no ano de 1325. Cf. Daniel Scherer, A raiz anti-tomista da modernidade filosófica (Formosa, GO: Edições Santo Tomás, 2017), 137.

32 A. S. McGrade, The Political Thought of William of Ockham: Personal and Institutional Principles (Cambridge, UK: Cambridge University Press, 1974), 12-13: o curioso é que ele, até então, a ela se opunha, tendo inclusive auxiliado na condenação de quatro de seus membros à fogueira em Marselha, em 1318.
} 
nas $^{33}$, mesmo motivo que o levara a ser aprisionado na carceragem pontifícia em Avignon, em 132434, de onde fugiria, em 1328, para Pisa, e depois para a corte de Luís da Baviera, eleito imperador do Sacro Império, com outro confrade, Bonagratia de Bérgamo, e o próprio Miguel de Cesena ${ }^{35}$. Ao primeiro teria dito, segundo uma lenda, "defende-me com tua espada, e te defenderei com minha pena" 36 , frase lendária, mas que expressa bem a fidelidade de Ockham à causa dos poderes seculares contra o papado, mantida no curso dos anos seguintes.

A obra escrita por ele para defender o seu superior, o Opus nonaginta dierum $^{37}$ (Obra de Noventa Dias), consistia numa resposta exaustiva à bula Quia vir. Ali o franciscano opunha, à concepção em ampla medida tomista adotada pelo então pontífice, uma doutrina complexa e inovadoramente estranha. Nessa obra reside boa parte da doutrina de Ockham a respeito do direito e da justiça, que será exposta mais adiante.

\subsubsection{Afluentes da doutrina ockhamiana, ou três modos de desprezar as mediações}

Com efeito, são muitos os contrastes entre a doutrina de Ockham e a de Tomás de Aquino, autor que consolidou a teoria jusnaturalista clássica, de Platão e Aristóteles, acerca da justiça, para que passem despercebidos. No entanto, para compreendê-los com suficiente precisão, é necessário atinar com os afluentes de sua doutrina, que, por sua vez, se desdobra em muitos outros braços.

Um destes afluentes é o espiritualismo franciscano, no qual, é interessante reparar, já confluem duas correntes de pensamento. A publicação da Introdução ao Evangelho Eterno, por Gerardo de Borgo San Donino O. F. M. ${ }^{38}$ pode ser considerada o marco inicial da seita dos espirituais. Nela o autor faz uma interpretação sobre o significado da ordem franciscana à luz da profecia escatológica do abade cisterciense Joaquim de Flora († 1202, autor de $O$ Evangelho Eterno), prevendo, devido à chegada do ano de 1260 (data vaticinada por Fiore), a ascensão de um governo dos espirituais fran-

33 McGrade, The Political Thought of William of Ockham, 7.

34 Servais Théodore Pinckaers, O. P.. Las fuentes de la moral cristiana (Navarra: EUNSA, 2007), 294.

35 Michel Villey, A formação do pensamento jurídico moderno (São Paulo: Martins Fontes, 2009), 267.

36 Pinckaers, O. P.. Las fuentes de la moral cristiana, 294.

37 Guillelmus de Occam, org. R. F. Benett et al., Opera politica, v.1 \& 2 (Manchester: Manchester University Press), 1963.

38 Assim como o nome oficial da Ordem Dominicana é Ordem dos Pregadores (Ordo Praedicatorum), também a Ordem Franciscana se chama, oficialmente, por outro nome: Ordem dos Frades Menores (Ordo Fratrum Minorum). 
ciscanos sobre todo o orbe, com o qual seria instaurado do Reino de Deus na Terra. ${ }^{39}$

Desde aí, é necessário distinguir entre aquela tendência ao imediato, característica da ordem franciscana e oriunda de sua tensão escatológica sobrenatural, consubstanciada na pretensão de viver o Evangelho sine glos$s a^{40} \mathrm{em}$ que se manifestava algo de um voluntarismo latente, tendente a prescindir de mediações naturais (das coisas materiais, pela via da pobreza) e mesmo de algo da tradição; e a exacerbação dessa tendência, com a contaminação pelo apelo profético do herege cisterciense milenarista Joaquim de Flora, caracterizado por sua previsão de uma iminente obsolescência dessas instituições, as quais logo se veriam substituídas pelo pleno soprar individual do espírito.

Para tanto, convém reparar no exemplo de S. Boaventura. Este, embora tenha sofrido o empuxo da profecia joaquimita acerca da ordem franciscana como aquela dos Tempos do Fim, não se deixou tragar por ela. Em sua interpretação, pelo contrário, ela ainda não era ainda a Ordem dos Tempos do Fim, mas apenas uma imagem desta, destinada a se realizar num futuro indeterminado. ${ }^{41}$ Para ele, ademais, a profecia de Joaquim de Flora, ao dividir a História em períodos exclusivamente correspondentes a cada uma das pessoas da Santíssima Trindade (Pai, Filho e Espírito Santo), errava crassamente ao desprezar a mediação perpétua divino-humana de Cristo (e, consequentemente, da própria Igreja).42

Daí, embora não se depreenda, torna-se possível ao menos compreender a postura de S. Boaventura, então geral da ordem, na querela da pobreza franciscana, a qual, por sua vez, girava em torno da interpretação da regra da ordem, que dizia que os frades não deveriam possuir nada em particular nem em comum. Seu Apologia Pauperum, embora marcado por um discurso voluntarista - insiste em que os franciscanos não poderiam ser considerados donos das coisas, mesmo que habitualmente as detivessem, contra sua vontade de "não serem donos" -, permanece ainda circunscrito aos limites da mediação da comunidade, na medida em que admite que o dominium do homem sobre as coisas temporais é sempre uma obra comum. Ali,

\footnotetext{
39 Daniel Rops, A Igreja das Catedrais e das Cruzadas, t. 3 de História da Igreja de Cristo (São Paulo: Quadrante, 2012), 620-621. Neste livro, de autoria do franciscano, anunciava-se o fundador da ordem como o "anjo do sétimo selo" referido no Apocalipse, a iminente ascensão dos franciscanos espirituais ao poder e, com isso, a chegada do Reino de Deus. 40 Isto é, sem anotações marginais, que por vezes se considerava distorcerem o significado do Evangelho. Cf. Joseph Ratzinger, La teología de la historia de san Buenaventura, (Madrid: Ediciones Encuentro, 2004), 76.

${ }^{41}$ Ratzinger, La teología de la bistoria de san Buenaventura, 98.

42 Ibid., 184.
} 
a palavra ius (direito) é invocada no ablativo (ex iure), isto é, como arranjo fontal comum do qual provém o título do dominium sobre as coisas criadas e no qual ele se insere, mas nunca como sinônimo deste. Por outro lado, esse seu voluntarismo avança contra aquilo que acredita serem meras convenções humanas, meras ficções, como a afirmação de que o uso não pode ser para sempre separado da propriedade (usum non potest perpetuo a dominio separari), e não contra a natureza enquanto tal. ${ }^{43}$

Esse voluntarismo, no entanto, já era uma semente de desordem. Com efeito, para ele, a liberdade de Deus era seu principal atributo, antes de sua vontade ou seu intelecto ${ }^{44}$, o qual se refletia na liberdade humana, uma faculdade acima da vontade e da razão. ${ }^{45}$ Boaventura, porém, rechaça um argumento baseado em Anselmo, segundo o qual Deus queria o possível, e o mal era possível, logo queria o mal ${ }^{46}$, e nega a vontade do mal também ao livre-arbítrio, enquanto livre ${ }^{47}$, embora reconheça a possibilidade de dispensa excepcional por Deus dos preceitos da segunda tábua do Decálo$\mathrm{go}^{48}$, relativos ao próximo. Para o Doutor Seráfico, o Verbo divino, exemplar de todas as criaturas, medeia a relação destas com o Criador, sendo Cristo mediador não apenas na teologia como na filosofia. ${ }^{49}$

Com Ockham, contudo, a coisa muda de figura. Ao voluntarismo latente dos franciscanos e ao orgulho dos espirituais, que ansiavam pela chegada de uma era que descartaria toda mediação das instituições (temporais ou eclesiais), somou-se, ainda, um individualismo exaltado, que se manifestou, no campo intelectual, na forma de nominalismo. Este era, na metafísica, a contraparte daquele desdém pelas instituições e pela tradição, já que, ao desprezar a mediação das espécies inteligíveis (species intelligibiles) como presentes nas coisas - isto é, ao afirmar que aos conceitos expressos pelos termos (signa artificiales) não correspondia nenhuma essência comum (signa naturales $)^{50}$, mas somente um agrupamento de indivíduos realizado segundo um amálgama de semelhanças selecionadas segundo fins pragmáticos

43 S. Buenaventura, ed. e trad. Bernando Aperribay (OFM) et al., Obras de San Buenaventura: tomo sexto y ultimo. (Madrid: Biblioteca de Autores Cristianos, 1949), 630 et passim.

44 Pinckaers, O. P., Las fuentes de la moral cristiana, 403.

45 Ibid., 447, n. 3

46 Divo Bonaventura, In Primum Librum Sententiarum Elaborata Dilucidatio (Venetiis: 1580), d. XLVI, a. I, q. II, 448-449.

47 Ibid., d. XXVI, p. II, a. I, q. III, p. 388-389.

48 Ibid., d. XLVII, a. I, q. IV, 459-460.

${ }^{49}$ Frederick Copleston, Medieval Philosophy: From Augustine to Duns Scotus, vol. 2 de A History of Philosophy (Image Books: New York, c1950), 259.

${ }^{50}$ Frederick Copleston, Late Medieval and Renaissance Philosophy: Ockham Francis Bacon and the beginning of the modern world, vol. 3 de $A$ History of Philosophy (Image Books: New York, c1953), 55. 
(aequivocitas a consilio) -, manifestava a pretensão de prescindir da própria natureza.

Ao fazê-lo, Ockham compromete não apenas o nível diacrônico (tradição) ou sinergético (instituição) da atuação da Cristandade, mas também seu nível sineidético (comunicação). Ao secundarem esse modo de pensar - para o qual a unidade se dissolve na multiplicidade sem peias, e para o qual a realidade da Igreja é comparável à de uma vara de porcos (sicut grex porcorum $)^{51}$-, as comunidades humanas, desprovidas de uma unidade simbólica, tendem a ser dissolvidas em meras coletividades, cujo destino, ao desatinarem com o elo constituído por aqueles significados comuns abstraídos a partir da natureza pela razão, será verem-se reduzidas a um mero receptáculo para uma multiplicidade diabólica (pois é isto que significa, estritamente: o contrário de "simbólico" de imagens desconexas (legião), e precipitadas paulatinamente no abismo do desentendimento e, daí, no do desamor. ${ }^{52}$

A partir do nominalismo, embora não se depreenda, torna-se possível compreender a moral ockhamiana. Afinal, se há apenas indivíduos isolados, parece haver se tornado impossível a participação no bem de outrem. Esta deriva imanentista já estava prefigurada na doutrina de Escoto, para quem a operação imanente da alma era mais importante no atingimento da visão beatífica do que qualquer elemento concomitante - no caso, Deus. Como afirma uma tomista argentina: "Poder-se-ia dizer que a 'forma' não participa em nada do 'fim' do ato, mas o objeto é certa causa do ato e por isso há dependência" 53 . E arremata: "Para Tomás, um ato voluntário é livre por causa da razão (mesmo que o sujeito da liberdade seja a vontade). A razão é causa como causa final e formal; ou seja, porque conhece a razão de bem, conhece por analogia o bem universal ou perfeito, e conhece diversos bens particulares (ratio est ad opposita). Em Escoto, o conhecimento deve concorrer como causa eficiente para que o ato não seja cego" ${ }^{54}$.

Apagada a participação dos objetos passíveis de escolha no fim último, resta apenas sua classificação sob a razão de contrários. Deste modo, a liberdade humana não será vista de uma maneira real e concreta, isto é, como potência para o bem, que permite à vontade a escolha do bem inteligido. Ela será, antes, vista como a capacidade indiferente de escolher quais-

51 Guillelmus de Occam. "Opus nonaginta dierum” em Opera politica, v. 1, org. por R. F. Benett et al.. (Manchester: Manchester University Press, 1963), c. 6, 366. 52 Acerca do tema, cf. David C. Schindler, Freedom From Reality: The Diabolical Character of Modern Liberty (Notre Dame: University of Notre Dame Press, 2017), cap. 5, 193-275.

53 Beatriz Eugenia Reyes Oribe, La voluntad del fin em Tomás de Aquino (Buenos Aires: Vórtice, 2004), 168.

54 Ibid., 171. 
quer contrários. Duns Escoto, o precursor de Ockham, que aprofundará seu voluntarismo ${ }^{55}$, apaga os elementos que tornavam possível a concepção tomasiana da voluntas ut natura. ${ }^{56}$

\subsubsection{Desdobramentos da doutrina jurídica de Ockham}

Ao analisarmos a doutrina jurídica de Ockham, é preciso reparar que a fonte principal de seu erro reside no orgulho, encontradiço, principalmente, no discurso do ramo espiritual do tronco franciscano, em relação ao qual esse pensador mantinha uma postura ao menos dúbia. ${ }^{57}$ Deste, emanavam, em primeiro lugar, a autossuficiência própria do seu individualismo e, em segundo, sua concepção naturalista acerca da situação do homem após o pecado original, eivada de racionalismo.

As sementes dessa pretensão de autossuficiência caracterizada na doutrina dos espirituais encontrou solo fértil no pensamento de Ockham para se desenvolver em brotos e ramos intelectuais. Sua noção de liberdade de pura indiferença entre dois contrários ${ }^{58}$, era uma continuação da doutrina de Escoto, que, como visto, mediante um movimento de esquecimento do Bem $^{59}$, tornava o objeto prescindível, em abstrato, para a bondade do ato volitivo.

Dentro de uma noção de liberdade que privilegia o poder de escolha como uma equidistância em relação aos contrários, as inclinações naturais passarão a ser encaradas sobretudo como obstáculos para a liberdade ${ }^{60}$. Assim, se a natureza (que, afinal, foi descartada pelo nominalismo como flatus vocis) e suas inclinações não constituem um caminho para se alcançar um significado ou, ao menos, um sentido para o ato moral; se a intelecção das essências está vedada como vereda para consecução do Bem, isto é, de Deus, restarão apenas as Escrituras e seus mandamentos. Deus, por sua vez, continuará a ser uma fonte de determinação moral, mas não porque Ele é uma causa exemplar para o mundo (pleni sunt coeli et terra gloria Tua) e abarca a plenitude do ser, e sim em razão da radical dependência da criatura ${ }^{61}$. A razão, em semelhante cenário, se resumirá a tentar demonstrar a necessidade de conclusões, em moral, a partir das premissas, como evidentes ${ }^{62}$.

55 Pinckaers, O. P., Las fuentes de la moral cristiana, 296 et passim.

56 Ibid., 178.

57 A. S. McGrade, The Political Thought of William of Ockham: Personal and Institutional Principles (Cambridge, UK: Cambridge University Press, 1974), 13.

58 Pinckaers, O. P., Las fuentes de la moral cristiana, 395.

59 Reyes Oribe, La voluntad del fin em Tomás de Aquino, 171.

60 Pinckaers, O. P., Las fuentes de la moral cristiana, 396.

61 Ibid., 404.

62 Pinckaers, O. P., Las fuentes de la moral cristiana, 409. 
A partir do estabelecimento da dependência em relação a Deus como fonte da sua autoridade para estabelecer a Lei, não surpreende que o mesmo venha a ocorrer em relação à Natureza. Por isso a insistência no pauperismo como foco da racionalidade espiritual franciscana: a reta razão leva a buscar somente a satisfação das necessidades; racional, para o homem, não é procurar viver bem, mas tentar sobreviver com o mínimo possível. A relação do homem com as realidades que lhe transcendem - sejam estas divinas ou naturais - dá-se à maneira do filho mais velho da parábola: ele não a vê como participação, mas como pura dependência, e esta, enquanto tal, não pode senão resultar, no longo prazo, odiosa. Não há participação (tudo que é meu é teu), apenas causalidade eficiente.

Deste modo, dentro de sua distinção entre três modos de Lei Natural, um deles ganha especial relevo. Ele consiste "naquilo que deveria ser observado pelos homens vivendo segundo as bases da equidade natural, sem nenhum costume ou constituição humana", pois o direito positivo, a propriedade e outras instituições econômicas, teriam sido desnecessárias, se todos vivessem de uma maneira racional, o que permitiria a manutenção da liberdade universal e da posse comum universal. ${ }^{63} \mathrm{Ou}$ seja, a visão de Ockham baseia-se na autossuficiência do indivíduo com a sua rąão, em independência da mediação das instituições humanas (outra afinidade com o ramo dos espirituais). Assim, vemos o mais rematado individualismo resultar, como num passe de mágica, no mais absoluto comunismo. Assim, comenta McGrade:

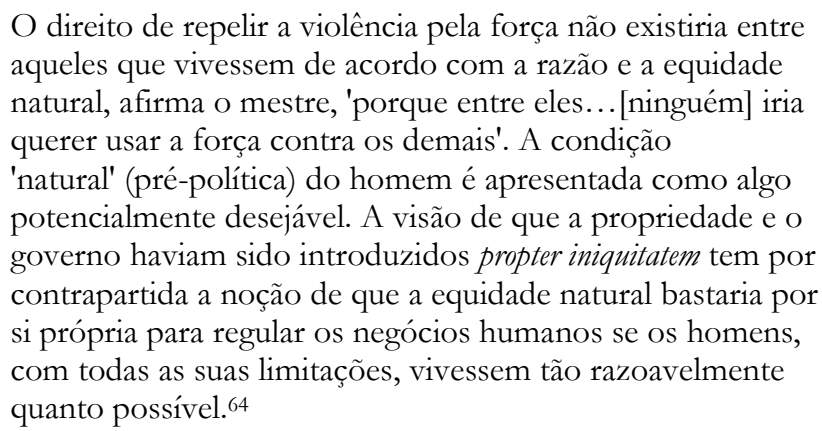

Desta maneira, a renúncia pauperista (ao menos chancelar), a tudo o que é supérfluo, constitui o mote para Ockham condensar duas categorias numa só: uma é a do ius naturale (direito natural), pela qual uma pessoa qualquer, em tempo de necessidade extrema, pode se valer de uma coisa qualquer sem a qual sua vida não pode ser preservada; a outra, a do ius poli

\footnotetext{
63 McGrade, The Political Thought of William of Ockham, 178-180.

64 Ibid., 180.
} 
(direito celeste), uma categoria mencionada pelo Papa Nicolau III na Exiit qui. Está implícita no pensamento de Ockham a idéia de que os franciscanos, ao renunciarem às superfluidades ${ }^{65}$, colocavam-se em um estado de necessidade voluntário, e tinham, portanto, direito, pelo ius poli, a todas as coisas - porque eles apenas se valem das coisas sem as quais a sua vida não pode ser conservada. ${ }^{66}$ Ao fazê-lo, Ockham constitui-se, provavelmente, no primeiro pensador a trazer o Estado de Exceção para dentro da regra.

Isto era apenas um consectário, obviamente, da grande ruptura ideada pela teologia de Ockham entre o Estado de Natureza Íntegra e o Estado de Natureza Decaída. Assim, contra o argumento de que Adão tinha o domínio sobre as criaturas da terra, Ockham assevera que tal domínio não era semelhante ao dos homens decaídos. Este é caracterizado pela recalcitrância da criação em servir ao homem, a qual deve ser constrangida com o uso da violência. ${ }^{67}$ Evidentemente, do uso da força contra uma criação rebelde não se seguiria que o homem perdeu sua razão, e que, portanto, o título de seu domínio absolutamente caducou, ainda que possa ter sido mitigado. No entanto, não é essa a conclusão que Ockham tira, ao pontificar que a natureza de um e a de outro domínio é totalmente diferente (totaliter alterius rationis). ${ }^{68}$ Para ele, contudo, a razão do domínio original é restituída com a simples adesão verbal ao postulado pauperista sustentado pela ala espiritual de sua ordem.

Segundo tal visão, era o gosto pelo supérfluo que arrojava o homem na irracionalidade e o mundo no desequilíbrio. Assim, à objeção de que os franciscanos também tinham um domínio sobre as coisas de que dispunham, apresentava o argumento de que essa categoria a eles não se aplicava. Não porque estivessem entravados de dispor, o que obviamente não podia negar, mas porque, ao fazê-lo, moviam-se apenas pela necessidade: eram proibidos, com efeito, de dar mais a quem necessitava menos e menos quem necessitava mais. ${ }^{69}$ Ao argumentar deste modo, Ockham deixa patente e claro que o único título de justiça admitido por seu ideado estado de justiça original é o da necessidade, e nenhum outro.

Evidentemente, uma concepção como essa não admitiria a ideia de um arranjo social voltado para a melhoria das condições materiais como aspec-

65 Guillelmus de Occam. "Opus nonaginta dierum” em Opera politica, v. 2, org. por R. F. Benett et al.. (Manchester: Manchester University Press, 1963), c. 11, 416.

66 Ibid., c. 65, 578 .

67 Guillelmus de Occam. "Opus nonaginta dierum” em Opera politica, v. 2, org. por R. F. Benett et al.. (Manchester: Manchester University Press, 1963), c. 14, 432.

68 Ibid., c. 28, 493.

${ }^{69}$ Guillelmus de Occam. "Opus nonaginta dierum” em Opera politica, v. 1, org. por R. F. Benett et al.. (Manchester: Manchester University Press, 1963), c. 4, 337. 
to da perfeição humana, aceitando outro título jurídico para além da mera necessidade. Em meio a este ideal de retorno por vias da pura razão a um estado pré-lapsário, o horizonte social e político é desalojado por uma narrativa que estritamente o vincula ao pecado original, baseado na ideia de uma situação hipotética e apolítica de autossuficiência e ausência de atribuição de bens aos indivíduos. Aí, a virtude da justiça, tal como concebida por S. Tomás, tampouco pode vicejar. Afinal, se ela consiste na constante e perpétua vontade de dar a cada um o 'seu', e a diferença entre o 'meu' e o 'teu' foi eliminada como mesquinharia, a justiça na acepção clássica, do ponto de vista ockhamiano, não passaria de um vício, por ser um esforço para adquirir o supérfluo.

Tendo em vista que, para S. Tomás, a sociedade política e a designação de bens para cada um é vista como não apenas permitida, mas legítima, sua concepção acerca da virtude da justiça admitirá três significados, dois próprios e um metafórico: a Justiça Legal ou Geral corresponderá a todos os atos de justiça referidos aos outros em geral, isto é, mediado pela lei, tendo em vista imediatamente o bem comum e mediatamente os demais; a Justiça Particular - que, por sua vez, comporta duas subespécies, a comutativa e a distributiva -, tem em vista imediatamente os particulares, que são participantes do bem comum, e mediatamente este; por último, S. Tomás admite ainda uma acepção metafórica, que corresponde à ordem interior das potências inferiores do indivíduo com referência às superiores.

Pois bem, para Ockham, apenas esta última será considerada justiça de uma maneira principal ${ }^{70}$, numa completa inversão do panorama tomasiano acerca desta virtude. Deste modo, assim como a sociedade civil e política é, para ele, instituída apenas propter iniquitatem, constituindo um acidente de percurso, também a interação entre os seres humanos no âmbito da justiça consistirá numa mera intercorrência. Seu voluntarismo extremado, excludente e antipolítico leva Ockham, para escapar à argumentação de que não há uso totalmente desvinculado da propriedade, a interpretar, portanto, o direito dos franciscanos a se utilizarem das coisas de que habitualmente se valem, como algo totalmente independente do direito do titular que é delas proprietário. Deste modo, a utilização, por eles, das coisas deixadas à sua disposição por este último é um direito em si, e a permissão (licentia) que ele dá não consiste numa vontade positiva de fazer alguém participar nos seus bens, mas numa mera suspensão da sua vontade, isto é, num levantamento de obstáculo (removens probibens) 71 a um direito que emana diretamente

70 Guillelmus de Occam. "Opus nonaginta dierum” em Opera politica, v. 2, c. 60, 557.

71 Ibid., c. 65, 579. Esse fato não passou despercebido a A. S. McGrade, The Political Thought of William of Ockham: Personal and Institutional Principles (Cambridge, UK: Cambridge University Press, 1974), 176. 
do indivíduo (ius poli), a título de sua recta ratio, cuja única finalidade admitida é atender à satisfação das necessidades (ad relevandas indigentias suas). ${ }^{72}$

Para Ockham, a acepção principal da justiça consiste na ordem interior do homem, isto é, numa ordem imanente segundo a qual as potências inferiores submetem-se às superiores. Mas se a potência mais elevada do homem é a vontade e, mais ainda, a vontade de indiferença, o título de justiça do homem a qualquer coisa advirá não de sua participação numa ordem que lhe transcende - seja esta natural, humana, ou sobrenatural. Ora, se a justiça passou a consistir na submissão à própria vontade, a pretensão se confundirá com o próprio direito. No ius poli, isto é mais nítido, na medida em que, se a coisa que considero ser meu direito é minha por necessidade, o outro é visto como obstáculo; mas isto não é muito diferente na sua concepção do ius fori, pois o principal elemento distintivo do direito do foro, oriundo de um pacto social, para Ockham, consistirá no poder de mover uma ação na justiça. ${ }^{73}$

Daí se depreendem outras três características da teoria da justiça de Ockham: (a) necessitarismo, derivado do racionalismo individualista e naturalista, segundo o qual a recta ratio consistirá na dedicação à satisfação de necessidades; (b) negativismo, pois, se justiça é a ordem imanente das potências inferiores às superiores na satisfação das próprias necessidades, não poderá haver propriamente ato de justiça - de dar a cada um o seu -, em relação a outro, mas apenas de injustiça, sendo a justiça, neste caso, a negação da negação do justo (o que é consubstanciado na noção de removens probibens); (c) bostilitarismo, se o outro, portanto, pode figurar apenas como obstáculo a minha justiça, que é minha relação com coisas exteriores para a satisfação das minhas necessidades, já que cada um, por força mesmo de sua autossuficiência, está ordenado pela popular "Lei de Murici"74, obviamente a relação com o próximo estará sempre marcada pela tensão de uma precariedade fundamentalmente hostil.

Tudo isto se baseava na ideia de que a determinação de porções de terra e outros bens para cada pessoa era algo inerentemente mau, fruto unicamente das injustiças, vistas como violências a que cada um estava sujeito no exercício do seu direito, conceituado como poder indeterminado

\footnotetext{
72 Esse reducionismo no uso dos bens exteriores para o mero atendimento das necessidades corporais é manifestado, no caso da obediência à lei moral divina, como uma mera submissão prestada a Deus por conta da dependência que Dele tem o ser humano para se manter no ser. Cf. Pinckaers, O. P., Las fuentes de la moral cristiana, 49, 68.

73 Guillelmus de Occam, "Opus nonaginta dierum" em Opera politica, v. 1, c. 4, 336. No entanto, o poder de ajuizar uma ação independe do direito que se tem, cuja pretensão pode ser infirmada ao final do processo, como se sabe.

74 "Lei de Murici: Cada um sabe de si."
} 
sobre a criação, e não como ao menos parcialmente oriundas da ignorância provocada por essa mesma indeterminação. Deste modo, a determinação exterior é vista como fruto do mau uso do poder do homem, e não como algo conveniente em si à organização dos homens em sociedade em busca do bem comum. Esse mau uso do poder está caracterizado somente, deste modo, como fruto de uma desordem interna, e não como também de uma ausência de ordem externa: ou seja, são os excessos de cada um ao buscar o próprio bem que constituem principalmente, e não apenas acidentalmente, a forma da injustiça - que era vista, por Tomás de Aquino, como por Aristóteles, como residindo sobretudo num defeito da vontade em relação ao bem do outro, que englobava também a hipótese de um defeito em outras virtudes, mas a transcendia. ${ }^{75} \mathrm{O}$ que isso parece esconder é um desprezo, uma desconsideração pelo outro enquanto outro, isto é, enquanto bom, na exata medida em que suas perfeições características me ultrapassam, de modo a se constituir apenas como um obstáculo à necessidade (ou um indigente, em relação a abastança) de outro.

No entanto, esta não é a realidade da sociedade humana, que se baseia justamente na ideia de que não somos autossuficientes; de que somos, como diz o título de um livro de MacIntyre, animais racionais dependentes. Mas essa dependência é relacional e relativa, e deriva do fato de que cada um de nós tem coisas sobrando em relação aos outros, mas também coisas faltando, e que a comunicação de bens entre nós não apenas é necessária, mas conveniente a nosso aperfeiçoamento, em certa medida, e conveniente à construção de uma coisa comum. Baseia-se num reconhecimento da participação, em que por esta palavra se entende também a comunicação: participamos dos bens dos outros e participamos nossos bens aos outros; participar é comunicar, e isso se tornou impossível na visão deturpada de um universo atomizado ideada por Ockham e acolhida pelo mundo moderno.

Além disso, e, por último, cabe comentar acerca da relação do homem com a lei divina, pois outro traço relevante da liberdade de indiferença de Ockham, é que ela faz desta a principal característica de Deus, antes que sua vontade e sua inteligência. Ou seja, Deus é mais Deus pela possibilidade de não ter criado um mundo belo e ordenado do que por este ato. Assim, sob um pretexto piedoso de salvaguardar a onipotência divina o franciscano inglês acaba por apresentar um argumento semelhante ao baseado em Anselmo rechaçado por S. Boaventura: "Toda vontade pode se conformar ao preceito divino: mas, Deus pode prescrever que a vontade criada $\mathrm{O}$ odeie, pois a vontade criada pode fazê-lo (e recusar, por conseguinte, a bem-aventurança e o fim último). Ademais, tudo o que pode ser um ato

75 Aristóteles, Ética a Nicômaco. 1130a20-1130b. 
reto nesta vida pode sê-lo na pátria [celeste]: pois bem, odiar a Deus pode ser um ato reto nesta vida, se Deus o manda, logo, também pode sê-lo na pátria celestial." 76

Ao fazê-lo, submete, antes, à impotência humana, a onipotência Divina, tornando-a semelhante àquela. Sob uma capa de racionalidade que pretende resguardar a onipotência do Criador, portanto, oculta-se sobretudo uma espécie de antropomorfismo. O "deus cristão" de Ockham é como um deus pagão piorado. Cada ato humano e cada resposta divina, inclusive a bem-aventurança, são completamente isolados entre si. Deste modo, a ausência de intrínseca racionalidade predicada por Ockham da própria liberdade divina não pode resultar senão também que a própria lei de Deus é um obstáculo. Ora, se o "deus cristão" é um deus arbitrário, imitá-lo será tornar-se também arbitrário. Do Deus segundo concebido por Tomás, que é puro ato de ser e a perfeição suprema, restou apenas a figura sugerida pela serpente a Adão e Eva no Paraíso. A imitação de Deus consistirá, agora, em pairar "além do bem e do mal", e sua filha, a liberdade de indiferença (acaso sou eu guardador do meu irmão?) degenerará, igualmente, no pecado de Caim: no ódio pelo irmão como obstáculo a ser removido.

Os diversos elementos da concepção teológica, filosófica, moral e jurídica de Ockham imprimirão profundamente seu caráter à Modernidade. Seu nominalismo; sua concepção acerca da liberdade de Deus, cuja principal característica, do ponto de vista da criatura, seria a dependência no ser; sua ideia acerca do direito natural como fundado essencialmente sobre a necessidade, que tornará a pretensão o significado principal do direito, concebido à revelia de um arranjo social (absque pactione). Este modo de pensar arrebanhará uma longa posteridade, a começar por alguns teólogos como Pierre D'Ailly ${ }^{77}$ e Jacques Almain ${ }^{78}$, e paulatinamente se estabelecerá - malgrado os esforços dos teólogos tomistas, já algo afastados da original filosofia tomasiana do Ser, incrustando-se nas fendas da formação deste - , com apoio dos poderes seculares (cabe lembrar que Ockham foi o primeiro teólogo de vulto a se pôr constantemente a serviço de um destes), tornando cada vez mais difícil a oposição a si como o modo principal de

\footnotetext{
${ }^{76}$ Guillielmus de Occam, IV Sent. q. XIV, D, dictum quintum .Praeterea omnis voluntas potest se conformare precepto divino: sed Deus potest precipere quod voluntas creata odiat eum, igitur voluntas creata potest hoc facere. Preterea omne quod potest esse actus rectus in via et in patria: sed odire Deum potest actus rectus in via ista si precipiatur a Deo: ergo et in patria» citado em Pinckaers O. P., Las Fuentes de la moral cristiana, 300.

77 A. S. McGrade, The Political Thought of William of Ockham, 175. Francis Oakley, "Gerson and D'Ailly: an admonition," Speculum, v. 40, n. 1 (Jan., 1965), University of Chicago Press: 74-83, 75-76.

78 Jacobo Almaini, “Quaestio Resumptiva de Dominio Naturali, Ecclesiastico \& Civili”, in Joannis Gersonii, Opera Omnia. Tomus Secundus: Ecclesiasticam Politeian et Disciplinam (Antwerpiae: Sumptibus Societatis, 1706), 961.
} 
considerar a natureza humana, seu comportamento, inteligência e relação com Deus. Conforme expressou Pinckaers: "A teoria da liberdade de indiferença, que está no coração do nominalismo, exerceu sua influência, concomitante à deste, em todo o pensamento ocidental, e se encontra um pouco por toda parte, inclusive naqueles que mal sabem seu nome". ${ }^{79}$

\subsection{1: o despertar do Leviatã}

Com a obra de Hobbes, as linhas mestras da concepção do Direito ideada por Ockham finalmente ganham uma importância cabal e sistemática. Estas eram, como já se viu: uma ideia do direito como poder emanado puramente do indivíduo ${ }^{80}$ e de sua recta ratio; a ideia da vontade alheia como mero obstáculo para a realização desse direito ${ }^{81}$, ou, no máximo, instrumento; uma ideia reducionista de Deus, cujo atributo principal é visto como o poder ${ }^{82}$; a Lei, seja ela divina ou humana, como determinação heterônoma, ou melhor, como delimitação extrínseca, a obstaculizar a realização plena de um direito concebido originalmente como poder ilimitado.

Evidentemente, em Hobbes, essas características ganharão um contorno um tanto mais brutal, na medida em que o homem hobbesiano não está dotado da recta ratio, no sentido ockhamiano, em que as paixões inferiores estão plenamente submetidas às potências superiores. Na verdade, para Hobbes, toda razão será uma recta ratio. ${ }^{83}$ A questão, portanto, na passagem do estado de natureza para o estado social consiste meramente numa diferença de grau: a razão continua a ser um mero cálculo para o alcance de objetivos oriundos de impulsos. Trata-se apenas de descobrir que a melhor maneira de alcançar tais objetivos consiste em conferir um poder ilimitado a um só homem ou grupo de homens.

Até então, a hipótese de um estado de mera natureza era uma mera hipótese teológica. No entanto, alguns fatos inspiraram Hobbes a imaginálo à guisa de uma guerra de todos contra todos: além da já conhecida referência às guerras de religião, a vida dos índios na América em suas guerras e práticas canibais, e, ainda, segundo Schmitt, a prática predatória da pirataria, tornada corriqueira ao longo do século XVII, serviram-lhe de inspiração. ${ }^{84}$

79 Pinckaers, O. P.. Las Fuentes de la moral cristiana, 411.

80 Thomas Hobbes, Leviathan or The Matter, Forme and Power of a Common-wealth Ecclesiasticall and Civill. (London: Andrew Crook, 1651), 64.

81 Ibid., 65, 138.

82 Ibid., 70.

83 Ibid., 18.

${ }^{84}$ Carl Schmitt, $O$ nomos da Terra no direito das gentes do jus publicum europaeum (Rio de- Janeiro: Contraponto: Ed. PUC-Rio, 2014), 184-188. 
Ockham supunha que o estado de natureza íntegra era um estado do qual não se deveria ter saído, e ao qual se deveria voltar; para ele o estado de necessidade é bom e conveniente para o homem. Para Hobbes, ao contrário, o estado de constante necessidade é um estado do qual o homem deve o quanto antes procurar sair.

Deste modo, assim como Ockham, "Hobbes erigiu toda sua doutrina moral e política com base em observações atinentes ao caso extremo" 85 . Mas as semelhanças entre ambos não param por aí. São muitas outras as características por eles compartilhadas, a começar pelo nominalismo ${ }^{86}$. Além disso, a doutrina teológico-filosófico-política de Hobbes também é sobretudo uma filosofia do possível e, portanto, da potência, a começar pelo estado de natureza que nunca se declara nitidamente atual ou possível, passando pela ideia de Deus visto sobretudo pelo lado de sua potência infinita. "Na doutrina política de Hobbes", escreve Strauss, "o poder torna -se pela primeira vez eo nomine um tema central. [...] 'Poder' é um termo ambíguo. Ele é potentia por um lado, e potestas [...], por outro [...] O interesse predominante pelo "poder" é tão somente o outro lado da relativa indiferença para com o actus", conclui. ${ }^{87}$

Além disso, sua teoria partilha outros traços com a doutrina de Ockham. Essa indiferença em relação ao ato, que não é senão uma indiferença em relação ao bem, envolve ainda a mesma noção de direito de Ockham: o direito natural é uma liberdade irrestrita, na qual a lei vem intervir. Neste sentido, porém, em Hobbes ela vai além: a dúvida hiperbólica acerca do bem do outro ${ }^{88}$ faz que seu sujeito de direitos veja o próximo não apenas como um obstáculo a remover (removens probibens), mas chega a entender que tem direito até mesmo aos corpos dos outros. Evidentemente, uma coisa não se deduz da outra. O homem de Hobbes, porém, não é um homem autossuficiente. No entanto, é um homem que justifica sua maldade como fruto de sua vulnerabilidade. Ele pode até não depender do próximo para se manter no ser, mas depende da sua inocência para não ser retirado deste. Deste modo, da suspicácia infundada sobre os desígnios do próximo, este, em seu estatuto de objeto, passa de mero obstáculo a instrumento dos desígnios do sujeito de direitos.

No plano internacional, o artifício ideado por Hobbes de instituição de um soberano, como tônica da Paz de Westfália, acarretava ao menos o sa-

\footnotetext{
${ }^{85}$ Leo Strauss, Direito Natural e História (São Paulo: Martins Fontes, 2014), 237.

86 Hobbes, Leviathan, 13.

87 Strauss, Direito Natural e História, 235-236.

88 Essa analogia foi apresentada por Pierre Manent, Enquête sur la démocratia. (Paris: Gallimard, 2007), 121.
} 
lutar efeito de tirar as guerras do contexto da privacidade e da selvageria, e trazê-las para o terreno da publicidade e da civilização, de modo que apenas nações - ou, antes, seus soberanos - permaneciam umas em relações às outras - ou uns em relação aos outros - como sujeitos em estado de natureza. ${ }^{89}$

Evidentemente, em um primeiro momento, isto não se traduzia exatamente desta maneira, uma vez que, na realidade, "os soberanos europeus permaneceram sendo uma família ligada pelo parentesco e pelo direito de sucessão"90. Conforme argutamente analisou Schmitt:

À primeira vista, nesse direito das gentes interestatal de soberanos iguais em direito, tudo parece depender do fino fio dos tratados com os quais esses Leviatãs se vinculam a si mesmos, do "pacta sunt servanda", da autovinculação contratual de soberanos que permanecem livres. Isso seria, de fato, um tipo de direito problemático e altamente precário, uma união de egoístas e anarquistas, cujas autovinculações lembrariam o gracejo acerca das "amarras com que um mágico prende a si mesmo". Na realidade, porém, mantiveram-se fortes vínculos tradicionais, com considerações de natureza eclesiástica, social e econômica $[\ldots] \cdot{ }^{91}$

Malgrado os efeitos iniciais salutares, a concepção hobbesiana do Estado não poderia deixar de representar a animalização e mecanização; a mercantilização e a divinização de uma sociedade baseada no dinheiro, constituída a partir de então sobre o modelo das emergentes sociedades anônimas do século XVII, algo que não passou despercebido a Schmitt, a despeito de sua profunda admiração por Hobbes como fundador do ius publicum europaeum:

Tampouco a pessoa representativa soberana foi capaz de conter o processo de mecanização da ideia do Estado que se cumpre ao longo do século seguinte. É uma expressão ideal de representação do Barroco, historicamente ligada ao século XVII e inserida no Estado absoluto dos Príncipes. Teve expressão bela e simples em um dos Stewarts, James I, “on a public stage". Em Hobbes não é pessoa o Estado como totalidade; a pessoa representativa é somente a alma do "homem magno" Estado. O processo de mecanização não se detém por virtude deste personalismo, mas é, ao contrário, aperfei-

89 A este respeito, escreveu Schmitt: "Em comparação com a brutalidade das guerras religiosas e de partidos que por natureza são guerras de aniquilação e nas quais os inimigos se discriminam mutuamente como criminosos e piratas, e em comparação com as guerras coloniais, conduzidas contra povos "selvagens", isso significa uma racionalização e uma humanização com efeitos profundos". Schmitt, O nomos da terra, 150-51.

90 Schmitt, O nomos da Terra, 155.

91 Ibid., 150-151. 
çoado por ele. O elemento personalista fica enovelado no processo de mecanização e nele fenece. ${ }^{92}$

Deste modo, cumpriu-se, de certa maneira, a profecia vaticinada por Samuel Parker, clérigo seiscentista adversário de Locke, em cuja opinião qualquer doutrina que tomasse por fundamento o consentimento dos governados, isto é, as teorias contratualistas, mesmo na versão hobbesiana, levariam ao republicanismo. ${ }^{93}$ Aliás, na opinião de Koselleck, "a teoria Hobbesiana do Estado absolutista já contém in nuce a idéia do direito de Estado civil, de forma que seu olhar, embora parta do contexto das guerras religiosas, alcança por si mesmo o século XVIII"94. De fato, foi ele mesmo quem enunciou, no Leviatã, o "fruto de seu trabalho, mas também sua vida, ou liberdade" 95 como bens postos em perigo pela vulnerabilidade do homem no estado de natureza. Contudo, se para Hobbes esses direitos ilimitados eram a matéria da justificação de um governo que precisava determiná-los pelo bem da unidade da paz ${ }^{96}$ - que para S. Tomás constituía o primeiro fim da comunidade política ${ }^{97}$-, para Locke, eles constituirão o próprio objetivo da união civil.

\subsection{Locke: os direitos do homem como luze origem da sociedade}

Com Locke, finalmente aquilo que viria a ser conhecido como "os direitos do homem" ganha forma não apenas como fonte de justificativa de um governo que deve limitá-los, a fim de evitar o conflito civil, mas também como objetivos a serem promovidos. Se com Hobbes o exitus, isto é, a fuga do medo da morte violenta levava os homens a entregarem o seu "direito da natureza" ilimitado nas mãos de um soberano que, contudo, mantinha-se em tal prerrogativa, agora o exitus mudaria de figura. Nota-se aí a passagem do primeiro objetivo da comunidade política segundo S. Tomás (unidade da paz), para o segundo (suficiência dos meios materiais). Afinal, Locke mantém a mesma concepção de Hobbes, segundo a qual a busca ou a inquirição pelo Sumo Bem é impertinente. ${ }^{98}$ Ora, se tal concepção é assim rechaçada, não resta ao apetite humano a atitude simiesca de

92 Carl Schmitt, El Leviathan en la Teoría del Estado de Thomas Hobbes (Buenos Aires: Struhart \& Cía, 2002), 33-34.

93 Cf. Richard Ashcraft, La Politique Révolutionnaire et les Deux traités du gouvernment de John Locke, trad. Jean-François Baillon (Paris: PUF, 1995), 116.

94 Reinhart Koselleck, Crítica e crise: uma contribuição à patogênese do mundo burguês (Rio de Janeiro: Contraponto, 2015), 25.

95 Hobbes, Leviathan, 61.

96 Ibid., 47.

97 S. Tomás de Aquino, Do Reino e outros escritos (São Paulo: Armada; 2017), 173.

98 John Locke, Ensaio sobre o Entendimento Humano (São Paulo: Martins Fontes, 2012) (II, XXI, \S 48-55), 272-277. 
pular de galho em galho, de satisfação em satisfação, como modo de realizar a sua felicidade, exceto por um pequeno detalhe, como se verá a seguir.

A passagem acima referida é acompanhada, no plano individual, de uma conduta individual no estado de natureza orientada já não pela conservação da vida biológica em si mesmo, mas sim relativamente a toda a espécie. Aliás, para Locke, não apenas o ser humano, mas toda a criatura deve ser preservada, a não ser que deva ser destruída por um objetivo mais elevado - que, em sua concepção, apenas pode ser a preservação da espécie. ${ }^{99}$ É neste sentido que a Lei Natural, que não é senão a Lei Divina, orienta o homem, que não poderá, por isso, não apenas ser privado de sua vida, mas também de sua liberdade e propriedade, considerados como meios necessários para tanto, de maneira que aquele homem que pela força está disposto a tomar aquilo que a mim pertence, deve ser considerado como imbuído de uma igual disposição de me matar, motivo pelo qual posso eu também matá-lo. 100

Sendo encarada a vida apenas como um processo que se protrai indefinidamente no tempo - como já se viu, ela não está de nenhuma maneira orientada a nenhum Bem Maior - também a acumulação de meios para tanto será encarada como algo ilimitado, exceto pela obrigação de que aos demais seja deixado o suficiente e de igual qualidade para sua própria sobrevivência. ${ }^{101}$ No entanto, essa impressão inicial de preocupação a respeito do comum é logo deixada de lado, pois, se por um lado a preservação da própria vida pareceria ser o princípio de onde promanava a necessidade da preservação da posse dos bens, esta é logo substituída por um princípio autorreferente: na verdade, diz Locke, o homem tem uma propriedade sobre si mesmo, de maneira que tudo aquilo que misturou com o seu trabalho, retirando do comum, é seu. ${ }^{102}$

No entanto, para Locke, após a invenção do dinheiro, essa acumulação ilimitada de riqueza deixou de ser imoral, na medida esta pode ser representada por aquele, o qual não é necessário para a sobrevivência dos demais. ${ }^{103}$ Essa acumulação ilimitada de poder de aquisição na forma de dinheiro ideada pelo autor é, por outro lado, reflexo de sua concepção de liberdade, com a qual se confunde, de certa maneira, a noção de auto propriedade. Não que a liberdade para Locke consista em fazer tudo aquilo que se quer. No entanto, desprovida de sua participação na natureza e privada de seu

99 John Locke, Dois tratados sobre o governo (São Paulo: Martins Fontes, 2005), \ 6, 384.

100 Ibid., \18-19, 397-398.

101 Ibid., $\ 38$, 416, algo reafirmado no $\ 46,429$.

102 Ibid., \44, p. 423-424.

103 Ibid., \ 46, p. 425-426. 
objeto próprio (o Sumo Bem), a liberdade será definida por referência a seu sujeito, passando a significar "autocontrole". Portanto, sua tarefa será sobretudo se opor às ânsias de fugir do maior desconforto presente, que levariam o sujeito a alguma forma de repouso, na forma de descanso ${ }^{104} \mathrm{ou}$ consumo. Isto se baseia na ideia de que o Maior Bem está totalmente ausente do mundo, e a ser alcançado num futuro indeterminado. ${ }^{105}$ Deste modo, para Locke, a produção e a poupança promovidos pelos "industriosos e racionais" passa a ser representada pelo dinheiro, símbolo do diferimento do consumo e do descanso, isto é, da autopropriedade e, portanto, da liberdade e da propriedade dos homens, a ponto de a posse de terras pelos que não fazem uso do dinheiro (como os índios americanos) não ser reconhecida por ele como propriedade. ${ }^{106}$

Num contexto em que o "desejado das nações", passou a ser não mais Deus, mas o dinheiro ${ }^{107}$, que atende a todas as coisas ${ }^{108}$, não faz nenhum sentido em perguntar, como se perguntavam os medievais, se um governante que estivesse publicamente em pecado mortal carecia ou não de domínio. ${ }^{109}$ A comunhão eclesial havia sido substituída pelo uso do dinheiro como fonte do título da propriedade, e aqueles que não conviessem nesse especioso concerto deveriam ser espoliados.

A este tipo de interpretação de Locke há os que contraponham a menção deste autor à Lei Divina, à qual o homem deveria se subordinar por ser obra Dele. O que poucos reparam é que este argumento é falho por duas razões. Uma delas é aquela apontada por Feser: se é verdade que os homens são obra do Criador, isto não menos se aplica aos animais ${ }^{110}$, motivo pelo qual haveria pouca justificativa para tal lei como fundamento dos direitos naturais do homem. Esta advém, segundo Locke, do fato de os homens serem "produto de um Fabricante infinitamente sábio e onipotente, [...]Sua propriedade, [...] dotado de faculdades semelhantes, [...] numa mesma comunidade de natureza"111. Mas, se este é o argumento, não se vê como, diante da suposição nominalista de Locke de que não conhecemos

104 Schindler, Freedom From Reality, 47-8.

105 Locke, Ensaio sobre o Entendimento Humano, (II, XXI, \51), p. 273.

106 John Locke, Dois tratados sobre o governo (São Paulo: Martins Fontes, 2005, 』 45, p. 424-425.

107 Esta parece ser, ao menos, a visão de Max Weber, A Ética Protestante e o "Espírito" do Capitalismo (São Paulo: Companhia das Letras, 2018), 46.

108 John Locke, Some considerations of the the consequences of the lowering of interest and raising the value of the money, in John Locke, The Works of John Locke in nine volumes (London: C. Baldwin, 1824) 2-116, 45.

109 Richard Tuck, Natural Rights Theories: Their Origin and Development (Cambridge: Cambridge University Press, 1981), 26 et passim.

110 Edward Feser, Locke (Oxford, Oneworld, 2007), 120.

111 Locke, Dois tratados sobre o governo civil, 385. 
as essências reais das coisas, mas apenas as nominais, que não são senão coleções de acidentes (isto é, qualidades) arbitrariamente amalgamadas, isso possa bastar. ${ }^{112}$ Afinal, se como afirmou um comentador americano, "não deixa de ser estranho fazer da habilidade de criar certos tipos de ideias irreais e insubstanciais o distintivo da moralidade"113, tal proteção torna-se extremamente nebulosa.

Além disso, a eficácia desta Lei Divina tal qual concebida por Locke é extremamente limitada. Tendo em vista o fato de ele designar a punição como a principal característica da Lei, a Lei Divina, com sua punição pósmorte, e a Lei Civil, a cuja pena se pode eventualmente escapar, passam para um segundo plano frente à Lei Filosófica ou da Opinião, que é aquela derivada dos juízos predominantes no círculo social a qual cada um se recomenda, a cujo juízo de censura ou reprovação nenhum homem pode escapar. ${ }^{114}$ Essa contradição evidentemente ainda é aumentada pela noção segundo a qual as igrejas constituem meras associações privadas, veiculada na Primeira carta sobre a tolerância. ${ }^{115}$ Como consequência dessa concepção, "a atribuição de direitos", afirma John Dunn, "perdeu qualquer pretensão inteligível de uma fundamentação independente da volatilidade das transformações culturais ou da instabilidade das animosidades intergrupais"116. Assim, o autor inglês seiscentista pavimentou, em grande medida, o caminho para tudo que observamos acontecer hoje.

\section{Como argumentou Feser:}

É interessante que o abandono, por Locke, das noções escolásticas de formas substanciais e fins naturais tenha acabado nitidamente por levar (mesmo que isso não fosse sua intenção) à possibilidade de atribuir "direitos" a animais não humanos e ao meio-ambiente, e à negação de direitos para ao menos alguns seres humanos, como os fetos e os severamente comprometidos mentalmente - consequências que alguns filósofos contemporâneos cujas posições metafísicas são, em muitos aspectos, tributárias das de Locke, estão bastante satisfeitos em endossar. [...]. Ainda assim, é difícil acreditar que poderia ser um acidente o fato de que o seguimento minucioso das implicações da metafísica de Locke leve sua própria visão de direitos a se transformar em algo que se parece com essas concepções contemporâneas. ${ }^{117}$

112 Feser, Locke, 118-119.

113 Steve Forde, Locke, Science and Politics (Cambridge: Cambridge University Press, 2013), 113.

114 Locke, Ensaio sobre o Entendimento Humano, II, XXVIII, \12, 379-380.

115 John Locke, Two Treatises of Government and A Letter Concerning Toleration, ed. Ian Shapiro (New Haven: Yale University Press, 2003), 220.

116 John Dunn, "Measuring Locke's Shadow," in Locke, Two Treatises of Government and A Letter Concerning Toleration, 270.

117 Feser, Locke (Oxford, Oneworld, 2007), 121. 
Essas noções correntes acerca dos direitos, como corolário do abandono da ideia de formas substanciais e de causas finais, evidentemente, não afetam apenas a apreciação dos direitos que devem ser atribuídos aos outros (p. ex., araucárias, tartarugas marinhas, fetos humanos), mas refletemse também na própria reclamação de estatutos jurídicos afirmados pelos indivíduos acerca deles próprios, como extrapolação da noção de autopropriedade. Como notou Pierre Manent:

Todas as «identidades» do indivíduo devem ser avalizadas pelo Estado e a sociedade tão logo tal indivíduo as declare suas, e elas possuem o direito a um «respeito» incondicional. No lugar de um poder separado da opinião [...] reivindica-se um poder estatal e social que aprova ativamente, abraça calorosamente, todos os modos de viver. [...] Não se sai da ordem individualista, nem da ordem burguesa. Cada um é considerado como um proprietário, cuja propriedade o Estado e a sociedade devem respeitar, mas uma propriedade que [...] comporta também as opiniões, os «valores», as «identidades», as «orientações». Eu sou legítimo proprietário de tudo o que sou. O Estado e a sociedade devem reconhecê-lo e declará-lo $[\ldots] \cdot{ }^{118}$

Evidentemente, isso não se deu do dia para a noite. Foram precisos cerca de três séculos para que os germes de tal doutrina se desenvolvessem em suas plenas consequências, não sem antes serem em grande parte acolhidas pelos materialistas franceses, precursores de 1789.

\section{Constitucionalismo e neoconstitucionalismo: ideologias totalitárias}

“O que é o terceiro estado?" À pergunta estampada no título de sua mais famosa obra, aquele que pode com justiça ser chamado o "pai" do constitucionalismo moderno, Emmanuel-Joseph Sieyès responde, sem titubear: "- Tudo!"119 Abeberando-se no materialismo ateu amplamente influenciado por Spinoza e Locke (por via de Condillac), nominalista, como não poderia deixar de ser, tal autor havia declarado que "A verdadeira metafísica consiste em descobrir o vazio de todos os sistemas metafísicos"120.

Evidentemente, de nada adiantou a Sieyès afirmar que, sendo o terceiro estado (isto é, a burguesia, em oposição à nobreza e ao clero) tudo, pretendia apenas ser alguma coisa; e que tendo insistido a todo custo denominar a reunião dos representantes deste "Assembleia Nacional" (ao contrário de

118 Pierre Manent, Cours Familier de Philosophie Politique (Paris: Gallimard, 2016), 53.

119 Emmanuel-Joseph Sieyès, Qu'est-ce que le tiers état? (Paris: Pagnerre, 1839), 32.

120 Citado em Chantal Delsol, La haine du Monde (Paris: Du Cerf, 2016), 133-134. 
Mirabeau, que pretendia designá-la apenas "assembleia do povo") 121, se declarasse favorável à limitação da soberania do Estado no Termidor do ano III da República, quando o terror jacobino já havia sido instaurado e os massacres da Vendeia já haviam sido iniciados. De sua obra, o que ficou foi a ideia de um poder constituinte ilimitado, expressa em O que é o terceiro estado?, a despeito de ele ter afirmado que acima dela está o direito natural.122 Esse conceito de Constituição, escreve um jurista italiano, "supõe um passo adiante rumo à expulsão de toda transcendência"123.

Menos conhecido, porém, é seu entusiasmo pela ideia de Direitos do Homem, e a semelhança da doutrina expressa por ele em seu projeto de Declaração, ideado como preâmbulo e chave de leitura da Constituição Francesa e rechaçado pela Assembleia Nacional, com a de Locke, em que afirma, dentre outras coisas, que "toda união social e, por conseguinte, toda constituição política não pode ter por objeto senão manifestar, estender e assegurar os direitos do homem e do cidadão. ${ }^{124 "}$ Ali, ele manifesta o seu entusiasmo pelo "poder do homem, indefinido em seus progressos, tornar todas as potências da natureza servas de suas necessidades" 125 , contexto em que "[o]s outros indivíduos se apresentam necessariamente como meios ou como obstáculos." 126

Deixa também expresso em tal documento que o homem entra em sociedade "se julgar que é para sua vantagem"127, que "esta união é uma vantagem, e não um sacrifício", algo a que "a razão o conduziria por si própria"128, afirmando, em bases claramente lockeanas, que "todo homem é proprietário de sua pessoa" 129 . A centralidade da liberdade é nítida na afirmação de que "[o]s limites da liberdade individual não se colocam senão no ponto onde ela começa a prejudicar a liberdade dos demais" 130 .

\footnotetext{
121 Manent, Cours Familier de Philosophie Politique, 93.

122 Sieyès, Qu'est-ce que le tiers état?, 129.

123 Danilo Castellano, "Constitución y Constitucionalismo", Revista Verbo 505-506 (2012): 357-364, 361.

124 Emmanuel Joseph Sieyès. "Mémoire préliminaire à la Constitution, lu le 21 juillet 1789 : exposition des droits de l'homme et du citoyen par Sieyès," in Archives Parlementaires de 1787 à 1860 - Première série (1787-1799) Tome VIII - Du 5 mai 1789 au 15 septembre 1789. (Paris : Librairie Administrative P. Dupont, 1875). 256-261; Disponível em: https://www.persee.fr/doc/arcpa_00000000_1875_num_8_1_6377_t2_0256_0000_6Fichier.pdf. Acesso em 13 jul. 2020. 125 Ibid., 256.

126 Ibid., 256.

127 Ibid., 257.

128 Ibid., 257 cf. também art. 3, 260.

129 Ibid., 257.

130 Ibid., 258.
} 
Consequentemente a essa visão típica de uma sociedade anônima, Sieyès admite à participação política apenas os que têm meios de contribuir financeiramente para o Estado, "verdadeiros acionistas da grande empresa social"131. Essa declaração de Sieyès, de certa maneira, sela a transição de uma política de pessoas e famílias, a que vimos Schmitt se referir acima, a uma política mecânica, de sociedades anônimas.

Da mesma raiz burguesa da idolatria nacional, que não é senão instrumento da idolatria de si mesmo, segundo o qual o outro ou é instrumento ou é inimigo, nasceram os diversos conflitos que varreram a Europa. Primeiro, dentro da própria França, cujo governo revolucionário se empenhava em apagar as marcas não apenas do Catolicismo como das pequenas culturas regionais, atitude cujo maior exemplo foi o massacre da Vendeia, com seu meio milhão de mortos, e também em guerras externas, cujo termo foi Waterloo. Após o período napoleônico, a intensidade dessas guerras externas intra-europeias foi mitigada pela divisão de esforços que as guerras de unificação e que a empreitada colonialista exigiam, mas logo voltaram a ocorrer, tendo essa escalada de violência culminado nas duas grandes guerras que varreram a Europa no início do século XX.

A segunda delas pôs novamente em evidência a centralidade do conceito de nação, embora a vontade geral que tenha afirmado seu protagonismo no séc. XX europeu tenha sido a da Alemanha. Ali, o totalitarismo havia demonstrado como eram suscetíveis as bases do Estado de Direito burguês às metamorfoses do seu ordenamento assentado sobre pressupostos nominalistas, em sociedades cada vez mais atomizadas, aos concertos e desconcertos dos homens.

Como aludido anteriormente, na seção primeira deste artigo, insatisfeita em ver sua meta alcançada - primeiro no Terror jacobino, depois no horror dos campos de concentração - a elite mundial resolveu dobrar a meta. Agora os vilões não eram mais os reis absolutistas e seu poder arbitrário, mas sim a nação, sua uniformidade étnica e sua lei positiva. Pois, se estes, no antigo constitucionalismo, eram vistos como imprescindíveis para a promoção dos direitos do homem, agora eram relegados como não apenas descartáveis, mas nocivos à consecução dessa tarefa, já que consistiam numa imposição de limites, contrários ao panteísmo de fundo ${ }^{132}$ disseminado pelos indivíduos por trás desse ideal de estado como instrumento, que o tornava em princípio infinitamente expansível de acordo com a variedade de desígnios que possam utilizá-lo. 133

131 Ibid., 259.

132 Cf. Reinhart Koselleck, Crítica e crise: uma contribuição à patogênese do mundo burguês (Rio de Janeiro: Contraponto, 2015), 76-77.

133 Pierre Manent, Enquête sur la démocratie (Paris: Gallimard, 2007), 87. 
Desta maneira, os direitos do homem eram novamente colocados no centro da discussão. Agora, sua promoção demandava não mais um órgão representativo nacional, soberano, para promulgar leis. Convinha, antes, um composto de especialistas, cujo papel consistiria, mais que em ecoar os anseios da nacionalidade, em servir de caixa de ressonância para o discurso dos direitos do homem, internacionalmente veiculado, com apoio de poderosas corporações meta-capitalistas, não apenas nos meios de formação jurídica ${ }^{134}$, mas também naqueles de difusão e produção de cultura em geral, e de uma mentalidade liberal, cuja referência intelectual mais proeminente é Karl Popper.

Relativamente a Sieyès, pouco mudou. A doutrina subjacente continua a ser a mesma: para a implantação de um contratualismo instrumental, e para a veiculação de pretensões individualistas virtualmente ilimitáveis, a nação tornou-se um artifício inapto, pois não era um martellus infinitus ${ }^{135}$. Era necessário expandi-lo além dos limites das nações. O epicentro desta nova fase da revolução? Os Estados Unidos da América.

Os principais arquitetos dessa doutrina, já aludidos anteriormente, foram os professores John Rawls, de Harvard, e Ronald Dworkin, da NYU. Duas ideias-chave formuladas pelo primeiro foram a de "posição original", sucedâneo pós-moderno e mais hipotético ainda para o "estado de natureza"136, e mais despersonalizante ainda que ele; e sua ideia de "razão pública"137, uma espécie de qigurate ${ }^{138}$ pós-moderno, que determina de que modo os princípios superiores da metafísica e da Religião Revelada podem vir aos homens, no meio de uma discussão pública travada nas instituições políticas "razoáveis" ideadas pelo autor.

Dentre os pontos a destacar na visão do segundo, estão o conceito de que a constituição norte-americana é não um documento jurídico histórico,

134 A esse respeito, não deixa de ser significativo o relato de Carlos Ignacio Massini Correas, Filosofía del Derecho: Tomo I - El Derecho, los Derechos Humanos y el Derecho Natural. (Buenos Aires: Lexis Nexis Argentina, 2005),, 214, acerca da Conferência sobre o Positivismo Jurídico de Bellagio, patrocinada pelo Rockfeller Center, que mantém esse centro de pesquisa no norte da Itália há quase 60 anos: https://www.rockefellerfoundation.org/ bellagio-center/

135 Manent, Enquête sur la démocratie, 86.

135 Cf. John Rawls, Uma teoria da Justiça, (São Paulo: Martins Fontes, 2011), c. 3, 144-226.

137 Cf. John Rawls, O liberalismo Político, (São Paulo: WMF Martins Fontes, 2011), 265-287.

138 Os zigurates assírios, que inspiraram a narrativa bíblica da torre de Babel, consistiam em construções (torres com escadas em espiral), projetadas para obrigarem os deuses a baixar aos homens na forma querida por estes últimos. Cf.L. Arnaldich Perot. "Torre de Babel," in Gran Enciclopedia Rialp (Madrid: Rialp s/d), 567. Cf. também. Biblia Comentada, ed. e com. Profesores de Salamanca, t. 1 (Madrid. Biblioteca de Autores Cristianos, 1960), 160. A visão da "escada de Jacob", no Antigo Testamento está relacionada com isso. Ao se declarar "a Escada de Jacob", Cristo afirma ser o verdadeiro mediador das comunicações entre o Céu e a Terra. 
mas sim uma carta de princípios ${ }^{139}$ generalíssimos (liberais, claro), alguns dos quais estão implícitos, mas nenhum dos quais pode ser contrariado, e o de que essa cosmovisão ali suposta é a de uma moralidade baseada em direitos $^{140}$, alguns não escritos ${ }^{141}$, que estão acima até mesmo do bem-comum ${ }^{142}$, dentre os quais se inclui, evidentemente, o "direito" ao aborto.

Tal "direito", para a alegria de Dworkin, foi mantido na decisão do caso Planned Parenthood v. Casey, em que ele próprio se ufana de ter sido citado. ${ }^{143}$ Ali se encontra, no voto dos ministros supostamente conservadores Kennedy, Souter e O'Connor, por ele comemorado, uma das passagens mais lamentáveis, piegas e absurdas da História do Direito, que expõe uma concepção completamente equivocista e, portanto, inviável de liberdade: "No coração da liberdade está o direito de cada um de definir o próprio conceito de existência, de sentido, do universo, e do mistério da vida humana"144.

Essa assertiva consiste nitidamente numa releitura da sentença de Protágoras, para quem "o homem é a medida de todas as coisas"145. Para Aristóteles, a doutrina desse sofista derivava da opinião dos naturalistas, que,

vendo que toda a realidade sensível está em movimento e que do que muda não se pode dizer nada de verdadeiro, [...] concluíram que não é possível dizer a verdade sobre o que muda, pelo menos que não é possível dizer a verdade sobre o que muda em todos os sentidos e de todas as maneiras. Dessa convicção derivou a mais radical das doutrinas mencionadas, professada pelos que se dizem seguidores de Heráclito e aceita também por Crátilo. Este acabou por se convencer ele que não deveria nem sequer falar, e limitava-se a simplesmente mover o dedo, reprovando até mesmo Heráclito por ter dito que não é possível banhar-se duas vezes no mesmo rio: Crátilo pensava não ser possível nem mesmo uma vez. ${ }^{146}$

${ }^{139}$ Ronald Dworkin, O direito da liberdade: a leitura moral da Constituição norte-americana. (São Paulo: WMF Martins Fontes, 2019), 11 et passim.

140 Ronald Dworkin, Levando os direitos a sério (São Paulo: WMF Martins Fontes, 2020), 266.

141 Dworkin, O direito da liberdade, 205.

142 Ibid., 551.

143 Ibid., 65.

144505 U.S. 833 (1992), 851. Disponível no site: https://supreme.justia.com/cases/ federal/us/505/833/case.pdf. Acesso em 12 jun. 2020. O documento não foi encontrado no site oficial da corte.

145 DK, 80, B1.

146 Aristóteles. Metafísica, ensaio introdutório, texto grego com tradução de Giovanni Reale, vol. 2, tradução do italiano de Marcelo Perine. (São Paulo: Loyola, c2002), Gama, 5 (1010a, 7-15), 169. 
"Efetivamente", continua o Filósofo, em parte escusando o efésio pela malversação de sua doutrina, "é impossível a quem quer que seja acreditar que uma mesma coisa seja e não seja, como, segundo alguns, teria dito Heráclito. Com efeito, não é preciso admitir como verdade tudo o que ele diz"147, "os que raciocinam desse modo", arremata, "suprimem a substância e a essência das coisas. De fato, eles devem afirmar que tudo é acidente e que não existe a essência do homem ou a essência do animal"148. No caso específico de Casey v. Planned Parenthood, tratou-se de afirmar que o feto "não é uma pessoa constitucional".

Essa postura vem sendo reproduzida com denodo por alguns de nossos constitucionalistas. Inocêncio Mártires Coelho, por exemplo, invoca, como Protágoras, a vulgata heraclítica ${ }^{149}$ para sustentar uma noção particularmente irresponsável de hermenêutica constitucional, segundo a qual "toda interpretação é apenas um experimento em marcha, assim como a ideia de uma interpretação definitiva é uma contradição nos termos da sempre oportuna lição de Hans-Georg Gadamer. Afinal, se tudo se transforma, se ninguém se banha duas vezes no mesmo rio - como se aprende com Heráclito-, seria uma excrescência que só a vida do direito escapasse ao panta rhei da eterna transformação."150

Não surpreende, igualmente, que o ministro Barroso, a seu turno, inicie um livro seu sobre este assunto citando ninguém menos que o nominalista Umberto Eco, para quem "nenhum texto pode ser interpretado de acordo com a utopia de um sentido autorizado definido, original e final", e para quem "o inacessível sentido literal [...] já se perdeu desde o início da emissão textual”"151. Em outra obra, de caráter geral, apresenta com entusiasmo a ideia da mutação constitucional, mediante a qual o poder constituído se transforma em poder constituinte difuso instanciado nas cortes de justiça, especialmente no STF. ${ }^{152}$

147 Ibid. ,Gama 4, (1005b, 23-26), 145. “Admitir como verdade”: tomar ao pé da letra. 148 Ibid., Gama 4, (1007a, 21), 153.

149 Acerca do equívoco de se atribuir tal posição a Heráclito, cf. Giovanni Reale e Dario Antiseri. Filosofia: Antiguidade e Idade Média, vol. 1. (São Paulo: Paulus, 2017), 34; Cornelio Fabro. Participation et causalité selon S. Thomas d'Aquin. (Langres: Parole et Silence, c2015), 87-105. Aniceto Molinaro. Metafísica: curso sistemático. (São Paulo: Paulus, 2004), 116. Edward Feser. Scholastic Metaphysics: A Contemporary Introduction. (Heusenstamm: Editiones Scholasticae, 2014), 33.

150 Inocêncio Mártires Coelho. "Hermenêutica Constitucional”. In: Ives Gandra da Silva Martins et al. (coord.). Tratado de Direito Constitucional, v.1. (São Paulo: Saraiva, 2012), 252. 151 Luís Roberto Barroso, Interpretação e aplicação da Constituição: fundamentos de uma dogmática constitucional transformadora. (São Paulo: Saraiva, 2004), 1.

152 Luís Roberto Barroso, Curso de direito Contitucional contemporâneo: os conceitos fundamentais e a construção do novo modelo. (São Paulo: Saraiva, 2009), 127 et passim. 
Embora Barroso até faça uma ressalva a respeito dos limites semânticos das palavras ${ }^{153}$, tal declaração soa no mínimo cínica, diante de toda sua atuação no STF, como advogado e como ministro, em que avultam violações frontais ao sentido de expressões como "o homem e a mulher"154 e "não há crime sem lei anterior que o defina"155.

Esse tipo de postura é revelador do caráter tecnológico do direito atual, que, como observou Tércio Ferraz Jr., "força a vida social, ocultando-a, ao manipulá-la, ao contrário da ciência prática da Antiguidade, que se prostrava, com humildade, diante da natureza das coisas", e arremata: "se, no passado, seria inconcebível imaginar que o instituto jurídico do matrimônio pudesse ser aplicado à relações homossexuais, na atualidade, por meio da manipulação conceitual, essa hipótese adquire viabilidade"156.

Mesmo antes de se tornar ministro, aliás, Barroso não se acanhava em designar a doutrina que defende como "ideologia", tampouco de expor sua sem-cerimônia em meter o nariz aonde não foi chamada:

O constitucionalismo democrático foi a ideologia vitoriosa do século XX. O imaginário social contemporâneo vislumbra nesse arranjo institucional [...] a melhor forma de realizar os anseios da modernidade [...] justiça social, tolerância e-quem sabe? —até felicidade. [...]. Os últimos anos representam, não a vitória de uma Constituição específica, concreta, mas de uma ideia, de uma atitude diante da vida. O constitucionalismo democrático que se consolidou entre nós, traduz não apenas um modo de ver o Estado e o Direito, mas de desejar o mundo, em busca de um tempo de justiça, fraternidade e delicadeza. ${ }^{157}$

"Nesse ambiente, promove-se uma reaproximação entre o Direito e a filosofia"158, afirma Barroso, noutro escrito. Seu marco filosófico, continua, é "o pós-positivismo", que, pontua, contesta "o postulado positivista de separação entre Direito, moral e política", promovendo uma "reentronização dos valores da interpretação jurídica, com o reconhecimento de normatividade aos princípios e de sua diferença qualitativa em

153 Ibid., loc. cit..

154 Cf. http:/ / redir.stf.jus.br/paginadorpub/paginador.jsp?

docTP=AC\&docID=628633\&fb_source=message o julgamento da ADPF 132, ajuizada por Barroso, quando ainda advogado, feito em conjunto com a ADI 4277 sobre a extensão do instituto da união estável para parelhas do mesmo sexo.

155 ADO 26/DF http://www.stf.jus.br/arquivo/cms/noticiaNoticiaStf/anexo/ tesesADO26.pdf.

156 Tércio S. Ferraz Jr, Introdução ao Estudo do Direito (São Paulo: Atlas, 2015), 59.

157 Luís Roberto Barroso, “A Constituição Brasileira de 1988: uma Introdução,” in Ives Gandra da Silva Martins et al. (coord.), Tratado de Direito Constitucional, v.1. 2. ed. (São Paulo: Saraiva, 2012), 45.

158 Luís Roberto Barroso, Neoconstitucionalismo e constitucionalizaçãa do direito, 3. 
relação às regras; a reabilitação da razão prática e da argumentação jurídica; a formação de uma nova hermenêutica; e o desenvolvimento de uma teoria dos direitos fundamentais edificada sobre a dignidade da pessoa humana"159. Eis como o neoconstitucionalismo se apresenta.

"Como ele realmente é", contudo, difere um pouco. Para Luis Fernando Barzotto:

\begin{abstract}
a experiência totalitária mostrou a necessidade de proteger valores básicos contra movimentos sociais ideologizados. Se estes movimentos alcançarem o poder, manipulando maiorias ocasionais, está aberta a possibilidade de dominação total mediante o uso da lei. Assim, o Estado Legislativo liberal, por manter-se neutro axiologicamente, está sujeito a servir de instrumento à "tirania das maiorias". A solução? Uma constituição repleta de princípios éticos que, efetivada por uma “jurisdição constitucional”, só reconheça como lei válida para o sistema as normas que se conformem com a moral constitucionalizada. ${ }^{160}$
\end{abstract}

No entanto, longe de oferecer uma solução ao problema do totalitarismo, essa concepção apenas o agrava, segundo o professor da UFRGS, pois era justamente "isso a que se propunha o estado totalitário: que não houvesse distinção entre ética e direito. Como afirma Hannah Arendt, o Estado Total não reconhece 'qualquer diferença entre lei e ética', porque a 'lei em vigor é idêntica à ética comum’. [...] Não há possibilidade de crítica moral ao direito positivo, porque não há moral para além da constituição: o direito legitima moralmente a si próprio"161.

Além disso, longe de oferecer a estabilidade que se espera de qualquer instituição, o neoconstitucionalismo se funda sobre areias movediças, como reparou o professor Danilo Castellano, ao citar um dos principais mentores dessa doutrina, para a qual "o significado das disposições constitucionais deve ser construído. Gustavo Zagrebelsky, por exemplo, sustenta [...] que o direito constitucional (contemporâneo) é um conjunto de materiais de construção, porém a construção em concreto não é obra da constituição em quanto tal, mas de uma política constitucional que se aplica às possivieis combinações deste material'162.

Segundo este modo de ver o mundo, antes que numa partilha, o Direito se estabelece como um jogo, e não dos mais equilibrados, pois, como afirmou o próprio ministro Barroso, em uma discussão com uma ativista pró-

159 Barroso, “A Constituição Brasileira de 1988”, 41.

160 Luis Fernando Barzotto, Teoria do Direito (Porto Alegre: Livraria do Advogado, 2017), 25.

161 Eod. loc.

162 Danilo Castellano, "Constitución y Constitucionalismo", Revista Verbo 505-506 (2012):

357-364, 363 (grifos no original). 
vida: "Admitindo que haja vida, e, portanto, trabalhando sobre a sua premissa, se você se mover, como eu me movo, por uma ética kantiana [sic!], e se a sua vida depende do sacrifício da minha liberdade individual, e eu não quero sacrificar minha liberdade individual, você perde". ${ }^{163}$

Portanto, engana-se redondamente quem pensa que este movimento auto-intitulado de neo-constitucionalismo, ou de pós-positivismo, difira de qualquer maneira significativa de seus antecessores. Pelo contrário, ele é uma exacerbação do constitucionalismo, substituindo uma assembleia de representantes da nação a declarar a lei, por um tribunal neoiluminista globalista a declarar os direitos.

Quanto ao positivismo, explica Barzotto que, "para Kelsen, 'norma inválida' é uma contradição em termos. [...] Não há normas 'nulas', mas apenas 'anuláveis' segundo um procedimento previsto pelo próprio ordenamento jurídico. [...] Isto significa que o ordenamento jurídico outorgou ao órgão encarregado de aplicar a norma geral de decidir 'dentro' da norma ou 'fora' dela"'164.

Conforme desenvolve Kelsen:

Mas também o fato de a decisão do tribunal [...] de qualquer outra instância que não seja a última $[. .$.$] permanecer válida$ enquanto não for anulada por uma instância superior, significa que estes órgãos recebem da ordem jurídica poder para criar, ou uma norma jurídica individual cujo conteúdo se encontra prefixado na norma jurídica geral, ou uma norma jurídica individual cujo conteúdo não se encontra predeterminado mas é estabelecido por estes mesmos órgãos—com a diferença de que a validade destas normas jurídicas individuais é apenas uma validade provisória [...] ao passo que tal já não vale na hipótese da norma individual em vias de passar em julgado criada pelo tribunal de última instância. ${ }^{165}$

Para Kelsen, continua Barzotto ${ }^{166}$, a interpretação do tribunal é sempre autêntica, e "pode produzir uma norma que se situe completamente forma da moldura que a norma a aplicar representa. [...] É fato bem conhecido que, pela via de uma interpretação autêntica deste tipo, é muitas vezes criado Direito novo - especialmente pelos tribunais de última instância". 167

163 Apud Flávio Gordon. Barroso, discípulo de Cálicles. In: Gazeta do Povo. Disponível em https://www.gazetadopovo.com.br/vozes/flavio-gordon/barroso-discipulo-de-calicles/. Acesso em 10 jul. 2020.

164 Luis Fernando Barzotto, Teoria do Direito (Porto Alegre: Livraria do Advogado, 2017), 17.

165 Hans Kelsen, Teoria Pura do Direito (São Paulo: WMF Martins Fontes, 2012), 298.

166 Barzotto, Teoria do Direito, 18.

167 Kelsen, Teoria Pura do Direito, 394-395. 
Arremata, então, o professor paranaense: tal solução será “a mais apropriada segundo o único critério disponível na teoria dos valores kelseniana - a subjetividade do julgador: 'o juízo de valor é determinado por fatores emotivos, e assim, essencialmente subjetivo, válido apenas para o sujeito que julga'. ${ }^{168 "}$ 'Deste modo, o Neoconstitucionalismo ou Pós-Positivismo não difere em nada em relação aos seus antecessores, constituindo apenas uma fase, em que sua equivocidade e seu caráter arbitrário e niilístico, já presentes na sua patogênese burguesa, tornam-se mais plenamente visíveis, travestidos sob o rótulo de valores. O neoconstitucionalismo do "você perde" é, na verdade, um neoconstitucioniilismo, e, a continuarmos nessa toada, como diria aquela que foi a responsável pela indicação de Barroso para a Suprema Corte, "todo mundo vai perder".

\section{Deus ou nada: do neoconstitucioniilismo ao constituciona- lismo do Bem Comum}

Se há algo que resulta particularmente claro desta apreciação crítica do neoconstitucionalismo é que, sob a pretensão de aproximar-se da filosofia, tal corrente de pensamento, na verdade, consiste numa nova irrupção do mito. Conforme intuiu Pierre Manent, a situação mitológica, isto é, préfilosófica e pré-política do homem:

$$
\begin{aligned}
& \text { é caracterizada por uma dupla abordagem que parece para nós } \\
& \text { necessariamente contraditória. De um lado, uma delas proce- } \\
& \text { de por disjunções: o que caracteriza os humanos é que eles } \\
& \text { não são animais e também que eles não são deuses; seres huma- } \\
& \text { nos são caracterizados pelo que não são. Por outro lado, a lei } \\
& \text { dinâmica deste mundo tripartite é a metamorfose de animais, } \\
& \text { humanos e deuses transformando-se uns nos outros—um } \\
& \text { deus com a cabeça de um cão, um humano com o corpo de } \\
& \text { um cavalo, etc. Os três grandes elementos do mundo existem } \\
& \text { somente tornando-se o que eles não são, ou misturando-se } \\
& \text { com o que não são. A revolução filosófica [...] consiste em } \\
& \text { dizer que uma coisa é o que ela é [...].169 }
\end{aligned}
$$

Os exemplos desta postura tornam a avultar no presente: a negação do reconhecimento da essência humana ao feto, passando pelas pretensões do STF de modificar a definição de casamento ou de criminalizar críticas à conduta abarcada por essa mudança, ou, ainda, criminalizar declarações que reafirmem o status ontológico imutável dos gêneros sexuais; chegando até a questão de um exame para defensor público, cujo gabarito indica ser

168 Barzotto, Teoria do Direito, 19.

169 Pierre Manent, Metamorphoses of the City: on the Western dynamic (Cambridge, Mass.: Harvard University Press, 2013), 33. 
correto o patrocínio pela Defensoria pública da pretensão de um homem que deseja ter suas feições alteradas em um procedimento cirúrgico com a finalidade de se tornar parecido a um lagarto, às expensas dos seus concidadãos, em nome do "direito à felicidade". ${ }^{170}$

Diante de um cenário como este, pouco importa o apelo a valores, pois eles não são parte da solução, mas sintomas do problema. "Eles são aquilo que confere, de fora, às coisas o que resta de sua bondade intrínseca desaparecida. Eles não são explicitamente nomeados senão a partir do século XIX, sobretudo em Hermann Lotze, hoje relativamente esquecido, e depois em Nietzsche"171, afirma Rémi Brague. O problema que essa concepção oculta é evidentemente o esquecimento do Ser, i. e., o obscurecimento da doutrina tomasiana do ser como ato intensivo, perfeição das perfeições, realidade cabal de máxima intensão, plena de significação, presente por essência em Deus e por participação nas criaturas, e não apenas como conceito abstrato de máxima extensão (e, por conseguinte, mero sinônimo de existência).

Como argutamente observou uma tomista argentina, quando esta metafísica dos graus de perfeição se perde, surge a necessidade, no caso do evolucionismo, "de embaçar as diferenças, já que o fim de uma espécie é ser outra: o inferior, alienando-se, transforma-se no superior. Em caráter definitivo, a evolução toma o lugar da perfeição"172. Deste modo, o ser humano, vendo em si próprio apenas uma vontade de indiferença, e bombardeado por estímulos cada vez mais excêntricos, vê-se franqueado a se tornar outra coisa, alcançando a máxima extensão conceitual por meio da modificação de seus acidentes (já que as essências são meras coleções arbitrárias deles), ou até mesmo de destruir-se a si mesmo como ato de suprema liberdade. ${ }^{173}$ Anything goes!

Desta maneira, o indivíduo que adota o nominalismo não deve ser ouvido, pois sua afirmação de que nada tem sentido, que tudo são coleções de acidentes arbitrariamente amalgamados em espécies, deve ser encarada como uma noluntas communicandi, uma vontade de não se comunicar, de não

170 Cf. a crítica de Lênio Luiz Streck, "O pan-principiologismo e o sorriso do lagarto", Consultor Jurídico, 22 mar. 2012, disponível em: https:/ /www.conjur.com.br/2012-mar-22/ senso-incomum-pan-principiologismo-sorriso-lagarto. Acesso em 28 abr. 2020.

171 Rémi Brague, Ancoras no céu: a infraestrutura metafísica (São Paulo: Loyola, 2013), 44-45.

172 Beatriz Eugenia Reyes Oribe, La voluntad del fin en Santo Tomás (Buenos Aires: Vórtice, 2004), 198-199.

173 Cf. o capítulo 5 do já mencionado livro de Dworkin, intitulado Acaso temos o direito de morrer?, em que o autor faz uma insistente defesa do direito à morte baseado na ideia de que a vida humana não é dotada de uma dignidade intrínseca. (Ronald Dworkin, $O$ direito da liberdade: a leitura moral da Constituição norte-americana. 2. ed. (São Paulo: WMF Martins Fontes, 2019), 209-234). 
se submeter intelectualmente aos significados das perfeições criadas. Uma concepção como a esposada em Planned Parenthood v. Casey, caso amplamente adotada, só poderia resultar numa tirania de multidões insociáveis, pois a incapacidade de comunicar ${ }^{174}$, ou seja, de amar, como retratado por Xenofonte, devido à ânsia pelo imediato ${ }^{175}$, é a característica chave do tirano, que o faz se associar a criminosos e licenciosos, gerando um ambiente de insegurança. ${ }^{176}$

Percebe-se, assim, que a concepção de liberdade de indiferença e o nominalismo andam de mãos dadas. Era o destino deste degenerar em atomismo, e o destino daquela degenerar em niilismo, pois o ente que não se encaminha para seu bem, isto é, para o seu fim, sua perfeição, não realiza o seu ser, e "o ser e o um são a mesma coisa"177, como disse Aristóteles. Isto termina igualmente no obscurecimento da verdade também enunciada por ele de que "o ser é melhor do que o nada"178. No caso do homem, não se pôr em marcha rumo a realização do seu ser comunitário, contemplativo e comunicativo, isto é, rumo a sua unidade, é deixar-se tragar pelo sentimentalismo, pela apropriação depredatória da realidade e pela fragmentação. $\mathrm{O}$ individualismo intimista sentimentalista, como tal, não é sustentável. Ele degenera no caos do transespecismo e do transsexualismo e das políticas afirmativas identitárias, que separam os indivíduos por grupos de acidentes aleatórios; em suma: na transvaloração dos super-homúnculos. ${ }^{179}$ Eles são os resultados macabros da renúncia ao reconhecimento de um referencial transcendente que confere sua perfeição aos entes, e às perfeições intermédias destes, pois as coisas se comunicam por meio de suas perfeições formais, iguais especificamente, e análogas entre si no concerto da Criação.

Este último conceito, a saber, o de criação, aliás, é outro cujo significado se perde na modernidade, pois a confusão entre ser e existência ${ }^{180}$ não permite reconhecer os graus de perfeição, que apontam para a perfeição

174 Cf. Xénophon, “Hieron ou Le Traité sur la Tyrannie” I, 26; VI, 13,.in: Léo Strauss. De la Tyrannie. (Paris: Gallimard, 1999), 14; 26.

175 Cf. Ibid., I, 30, 14-15

176 Cf. Ibid.,. V, 2; VI, 3-4, 23; 24.

177 Aristóteles, Metafísica, ensaio introdutório, texto grego com tradução de Giovanni Reale, vol. 2, tradução do italiano de Marcelo Perine (São Paulo: Loyola, c2002), Gama, 2 (1004b23), 133

178 Aristóteles, De Generatione Animalium, 731b30, no vol. 3 das Opera Omnia: graece et latine (Paris: Ambrosio Firmin Didot, 1854), 344

179 Schindler, Freedom from Reality, 208.

180 Ela começou mesmo antes de Ockham, com Dietrich de Freiberg, cf. Daniel Scherer. $A$ rair. antitomista da modernidade filosófica. (Formosa, GO: Edições Santo Tomás, 2018), 138 et passim. Brague remonta as origens dessa posição a Averróis, Cf. Rémi Brague, Ancoras no céu: a infraestrutura metafísica, trad. de Nicolas Campanário (São Paulo: Loyola, 2013), 44. 
suprema e imutável, motivo pelo qual tanto tão confusão quanto a cosmovisão (ou melhor, caosvisão) em que ela desemboca, o evolucionismo ${ }^{181}$, devem ser o quanto antes rechaçados.

A esse respeito, escreve Brague: “«a Evolução!». A maiúscula que ele [o homem da rua] coloca na palavra, como o fazemos para um nome próprio, ajuda-lhe a vê-la como um agente consciente, ao mesmo tempo em que se trata, ao contrário, de recusar ao processo qualquer caráter intencional. 182" Ora, quem diz "intencional" diz "intelectual”, i. e., "racional".

Como afirmou o Papa Bento XVI, a grande questão consiste em "se a razão, ou o racional, acha-se no começo de todas as coisas e no fundamento delas, ou se o real surgiu em virtude do acaso ou da necessidade (ou, conforme Popper, que segue Butler, por luck e cunning, feliz casualidade e previsão); ou seja, surgiu do irracional”, “ou se, pelo contrário, permanece sendo verdade a convicção básica da fé cristã e da sua filosofia: In principio erat Verbum". E conclui: "pode a razão renunciar à prioridade do racional sobre o irracional, ao caráter primordial do logos, sem suprimir-se a si mesma?"183

A essa pretensão de autodeterminação (selbstbehauptung) da liberdade de indiferença, que leva o homem a cultuar divindades impessoais, sejam elas maquinais ou animalescas, Rémi Brague reapresenta a proposta cristã: a anakephalosis, a recapitulação de todas as coisas no Verbo criador. ${ }^{184} \mathrm{O}$ Verbo é a própria chamada ao Ser, e essa chamada não é uma chamada indeterminada. “«No princípio era o Verbo» [...] no texto bíblico o logos existe antes de mais nada como mandamento. [...] «Sê o que tu és» aparece desse modo como mandamento primeiro. [...] «Sê aquilo que tu deves ser!» Não: «Sê tua natureza!», segundo a máxima estoica, mas antes: «Sê aquilo a que te chamou a tua natureza no ser! ${ }^{185}{ }^{\prime \prime}$

Cada série de mandamentos abarca uma realidade face ao seu contrário e contra o pano de fundo composto por este. Tratase de destacar aquilo que é do que não é: das nações do mundo, dos escravos e dos homens servis, dos animais, dos minerais inanimados, e enfim, do nada puro e simples. [...] A Bíblia

\footnotetext{
181 Efetivamente, esta é a caos-visão subjacente ao neoconstitucionalismo, como demonstra bem a alusão a uma frase de Woodrow Wilson sobre a prestação de contas devida pelo governo constitucional a "São" Darwin feita por Luís Roberto Barroso, Interpretação e aplicação da Constituição: fundamentos de uma dogmática constitucional transformadora (São Paulo: Saraiva, 2004), 146, n. 157.

182 Rémi Brague, Le propre de l’homme: sur une légitimité menacée (Paris: Flammarion, 2013), 198.

183 Joseph Ratzinger, Fé, Verdade, Tolerância (São Paulo: Ramon Llull, 2015), 164-166.

184 Brague, Le propre de l'homme, 185-186.

185 Ibid., 239-240.
} 
começa por distinguir o ser do nada. Podemos tirar uma consequência importante no que diz respeito à sanção correspondente ao desrespeito dos mandamentos. No limite, não se trata senão da saída do domínio daquilo que se é, à perda das características que definem algo e à entrada num determinado nada [...] deixar de ser livre e se tornar escravo, de ser humano e tornar-se animal, deixar de ser vivo e morrer, deixar de existir e desaparecer. ${ }^{186}$

"Mas," prossegue Brague, "permanecemos num imperativo hipotético: se para o homem deve haver um ser, então um certo «fazen» é exigido. Mas quem pode nos dizer que o ser deve existir? Quem pode [...] nos dizer que é bom que estejamos aí, que nossa presença, que nossa posse de características que nos tornam homens é legítima? Quem, senão Deus?"187 O sentido da Lei, compreendido face ao relato da criação, consiste na recapitulação de todos os mandamentos num único: sejas! Desde esse ponto de vista, a autonomia e a heteronomia se deixam de opor uma à outra para se complementarem. ${ }^{188}$

Revelada a essência do neoconstitucionalismo como neoconstitucioniilismo, somos, portanto, confrontados com uma escolha: "o Ser ou o nada", ou, como diz o título do livro do Cardeal Robert Sarah: "Deus ou nada".

Na seara do Direito Constitucional contemporâneo, encontramos alguns exemplos desta postura. Nos Estados Unidos, por exemplo, os professores Adrian Vermeule ${ }^{189}$, de Harvard, e Hadley Arkes, emérito do Amherst College, ambos convertidos ao catolicismo na última década ${ }^{190}$, têm advogado uma superação do mero originalismo na interpretação da Constituição Norte-Americana. Nas palavras do primeiro, "um constitucionalismo moral substantivo, que, conquanto não seja escravo do sentido original da Constituição, seja também livre da narrativa sacramental global da esquerda liberal acerca da obsessiva expansão da autonomia individual", baseado num "reconhecimento de que toda legislação é necessariamente fundada em alguma concepção substantiva de moralidade"191.

\footnotetext{
186 Ibid., 230-231.

187 Ibid., 244.

188 Ibid., 243.

189 Entrevista disponível em https://www.firstthings.com/blogs/firstthoughts/2016/11/ finding-stable-ground, consultado em 13 de mai de 2020 .

190 Christopher Ferrara, Liberty: the god that failed: policing the sacred and constructing the myths of the secular state from Locke to Obama (Tacoma, WA: Angelico Press, 2012), 635.

${ }^{191}$ Adrian Vermeule, "Beyond Originalism", The Atlantic, 31-03-2020, disponível em: https://www.theatlantic.com/ideas/archive/2020/03/common-goodconstitutionalism/609037/ Acesso em 12 jul. 2020.
} 
Mal chegada ao Brasil, esta ideia foi recebida com desdém ${ }^{192}$ por um de nossos juristas, que há algum tempo admitia haver largado o neoconstitucionalismo. ${ }^{193} \mathrm{Em}$ meio a sua apreciação sardônica, declara-se cristão, mas demonstra seguir alinhado àqueles que desejam ver triunfar o "sorriso do lagarto"194. No entanto, se nossa opção é realmente entre "Deus e o nada", não temos por que lhe dar ouvidos. É preciso continuarmos na direção da Luz, deixando para trás as bases nominalistas e as piruetas retóricas emotivistas 195 da Modernidade rumo a uma fundamentação calcada numa metafísica do ato de ser intensivo. ${ }^{196}$

192 Lênio Luiz Streck, "Professor de Harvard lança 'constitucionalismo Deus acima de todos', Consultor Jurídico, 23 abr. 2020, disponível em: https://www.conjur.com.br/2020abr-23/senso-incomum-professor-harvard-lanca-constitucionalismo-deus-acima-todos. Acesso em 03 mar. 2020.

193 Lênio Luiz Streck, "Eis porque abandonei o 'neoconstitucionalismo"”, Consultor Jurídico, São Paulo, 13 mar. 2014, disponível em: https://www.conjur.com.br/2014-mar-13/sensoincomum-eis-porque-abandonei-neoconstitucionalismo. Acesso em 15 mar. 2020.

194 Explica-nos um autor francês: "o Leviatã é um animal mítico [...]. A Septuaginta e a Vulgata o denominam frequentemente draco. [...] Santo Alberto Magno, no seu comentário ao Livro de Jó $(3,8)$, declara que o Leviatã simboliza Satã, a antiga serpente venenosa. São Tomás o afirma também na sua Suma Teológica." Maxence Hecquard, Les fondements philosophiques de la démocratie moderne (Paris: François-Xavier de Guibert, 2010), 273.

195 Acerca do conceito de 'emotivismo', cf. Alasdair MacIntyre, Depois da Virtude (São Carlos, SP: EDUSC, 2001), especialmente o cap. 3.

196 Essa é a proposta do mesmo Alasdair MacIntyre. Three Rival Versions of Moral Enquiry: Encyclopedia, Genealogy and Tradition (Notre Dame, Indiana: University of Notre Dame Press, c1990), 122. 


\section{Referências Bibliográficas}

505 U.S. 833 (1992), 851. Disponível no site: https://supreme.justia.com/ cases/federal/us/505/833/case.pdf,. Acesso em 12 jun. 2020.

Almaini, Jacobo. "Quaestio Resumptiva de Dominio Naturali, Ecclesiastico \& Civili". In Joannis Gersonii. Opera Omnia. Tomus Secundus: Ecclesiasticam Politeian et Disciplinam. Antwerpiae: Sumptibus Societatis, 1706.

Arendt, Hannah. Sobre a Violência. Rio de Janeiro: Relume Dumará, 2001.

Aristóteles. De Generatione Animalium. In Opera Omnia: graece et latine, volume 3. Paris: Ambrosio Firmin Didot, 1854.

. Ética a Nicômaco.

. Metafísica, volume 2. Tradução de Giovanni Reale e Marcelo Perine. São Paulo: Loyola, c2002.

Ashcraft, Richard. La Politique Révolutionnaire et les Deux traités du gouvernment de John Locke. Traduzido por Jean-François Baillon. Paris: PUF, 1995.

Assemblée Nationale. Déclaration des Droits de l'Homme et du Citoyen de 1789. (Paris: Légifrance). Disponível em https://www.legifrance.gouv.fr/ Droit-francais/Constitution/Declaration-des-Droits-de-l-Homme-etdu-Citoyen-de-1789. Acesso em 19 jul. 2020.

Barroso, Luís Roberto. Interpretação e aplicação da Constituição: fundamentos de uma dogmática constitucional transformadora. São Paulo: Saraiva, 2004.

- "Neoconstitucionalismo e constitucionalização do direito: o triunfo tardio do direito constitucional no Brasil". Revista de Direito Administrativo 240 (abr/jun 2005): 1-42.

- Curso de direito Contitucional contemporâneo: os conceitos fundamentais e a construção do novo modelo. São Paulo: Saraiva, 2009.

. “A Constituição Brasileira de 1988: uma Introdução.” In Ives Gandra da Silva Martins et al. (coord.), Tratado de Direito Constitucional, v.1. 2. ed. São Paulo: Saraiva, 2012.

. "Contramajoritário, Representativo e Iluminista: Os papeis dos tribunais constitucionais nas democracias contemporâneas". Direito e Práxis 9, n. 4 (2018): 2171-2228.

Barzotto, Luis Fernando. Teoria do Direito. Porto Alegre: Livraria do Advogado, 2017.

Biblia Comentada. Editada e comentada por Profesores de Salamanca, volume 1. Madrid. Biblioteca de Autores Cristianos, 1960. 
Bobbio, Norberto. A Era dos Direitos. Rio de Janeiro: Campus, 2002.

Bonaventura. In Primum Librum Sententiarum Elaborata Dilucidatio. Venetiis: 1580.

Brague, Rémi. Âncoras no céu: a infraestrutura metafísica. Traduzido por Nicolas Campanário. São Paulo: Loyola, 2013. . Le propre de l'homme: sur une légitimité menacée. Paris: Flammarion, 2013.

Buenaventura. Obras de San Buenaventura: tomo sexto y ultimo. Editado e traduzido por Bernando Aperribay (OFM) et al. Madrid: Biblioteca de Autores Cristianos, 1949.

Carbonell, Miguel. Neoconstitucionalismo(s). Madrid: Trotta, 2003.

Castellano, Danilo. "Constitución y Constitucionalismo". Revista Verbo 505 -506 (2012): 357-364.

. "El problema de la Constitución y la Ideología Constitucionalista". Revista Verbo 513-514 (2013): 181-202

Coelho, Inocêncio Mártires. "Hermenêutica Constitucional". In Ives Gandra da Silva Martins et al. (coord.). Tratado de Direito Constitucional, volume 1. São Paulo: Saraiva, 2012.

Copleston, Frederick. Medieval Philosophy: From Augustine to Duns Scotus, volume 2 de $A$ History of Philosophy Image Books: New York, c1950. . Late Medieval and Renaissance Philosophy: Ockham Francis Bacon and the beginning of the modern world, volume 3 de $A$ History of Philosophy. New York: Image Books, c1953.

Correas, Carlos Ignacio Massini. Filosofía del Derecho: Tomo I - El Derecho, los Derechos Humanos y el Derecho Natural. Buenos Aires: Lexis Nexis Argentina, 2005.

Delsol, Chantal. La haîne du monde: totalitaristmes et postmodernité. Paris: Du Cerf, 2016.

Dunn, John. "Measuring Locke's Shadow". In John Locke, Two Treatises of Government and A Letter Concerning Toleration. Editado por Ian Shapiro. New Haven: Yale University Press, 2003.

Dworkin, Ronald. O Direito da Liberdade: a leitura moral da Constituição norteamericana. 2. ed. São Paulo: WMF Martins Fontes, 2019.

_. Levando os direitos a sério. São Paulo: WMF Martins Fontes, 2020.

Fabro, Cornelio. Participation et causalité selon S. Thomas d'Aquin. Langres:

Parole et Silence, c2015. 
Fernandes, Henrique Montagner. “'O nosso papel é empurrar a História (...) a serviço da causa da humanidade’: construção, reprodução e reação à doutrina neoconstitucionalista no Brasil." Tese de Doutorado em Direito, Universidade Federal do Rio Grande do Sul, 2020.

Ferrara, Christopher. Liberty: the god that failed: policing the sacred and constructing the myths of the secular state from Locke to Obama. Tacoma, WA: Angelico Press, 2012.

Ferraz Jr., Tércio S. Introdução ao Estudo do Direito. São Paulo: Atlas, 2015.

Feser, Edward. Locke. Oxford, Oneworld, 2007. . Scholastic Metaphysics: A Contemporary Introduction. Heusenstamm: Editiones Scholasticae, 2014.

Forde, Steve. Locke, Science and Politics. Cambridge: Cambridge University Press, 2013.

George, Robert P. Conscience and its enemies: confronting the dogmas of secular liberalism. Willmington, Delaware: ISI Books, 2013.

Glendon, Mary Ann. Rights Talk: the impoverishment of political discourse. New York: The Free Press, 1991.

Gordon, Flávio. "Barroso, discípulo de Cálicles”. Gazeta do Povo. Disponível em https://www.gazetadopovo.com.br/vozes/flavio-gordon/ barroso-discipulo-de-calicles/. Acesso em 10 jul. 2020.

Hecquard, Maxence. Les fondements philosophiques de la démocratie moderne. Paris: François-Xavier de Guibert, 2010.

Hobbes, Thomas. Leviathan or The Matter, Forme and Power of a Commonwealth Ecclesiasticall and Civill. London: Andrew Crook, 1651.

Israel, Jonathan. Democratic Enlightment: Philosophy, Revolution and Human Rights 1750-1790. Oxford: Oxford University Press, 2013).

Kelsen, Hans. Teoria Pura do Direito. São Paulo: WMF Martins Fontes, 2012.

Koselleck, Reinhart. Crítica e crise: uma contribuição à patogênese do mundo burguês. Rio de Janeiro: Contraponto, 2015.

Lafer, Celso. A reconstrução dos Direitos Humanos. São Paulo: Companhia das Letras, 1991.

Locke, John. Some considerations of the the consequences of the lowering of interest and raising the value of the money. In The Works of John Locke in nine volumes. London: C. Baldwin, 1824. 
. Two Treatises of Government and A Letter Concerning Toleration. Editado por Ian Shapiro. New Haven: Yale University Press, 2003. . Dois tratados sobre o governo. São Paulo: Martins Fontes, 2005. . Ensaio sobre o Entendimento Humano. São Paulo: Martins Fontes, 2012.

Lopes, José Reinaldo de Lima e Oscar Vilhena Vieira. "Religião e Direitos Humanos”. Opinião, O Estado de São Paulo (São Paulo, SP), 22 abr. 2013.

MacIntyre, Alasdair. Three Rival Versions of Moral Enquiry: Encyclopedia, Genealogy and Tradition. Notre Dame, Indiana: University of Notre Dame Press, c1990.

_. Depois da Virtude. Trad. Jussara Simões. São Carlos: EDUSC, 2001.

Manent, Pierre. Enquête sur la démocratie. Paris: Gallimard, 2007. . Metamorphoses of the City: on the Western dynamic. Cambridge, Mass.: Harvard University Press, 2013.

- Cours Familier de Philosophie Politique. Paris: Gallimard, 2016.

. La loi naturelle et les droits de l'homme. Paris: PUF, 2018.

Maritain, Jacques. Les droits de l'homme. Paris: Desclée de Brouwer, 1989.

McGrade, Arthur Stephen. The Political Thought of William of Ockham: Personal and Institutional Principles. Cambridge, UK: Cambridge University Press, 1974.

Molinaro, Aniceto. Metafísica: curso sistemático. São Paulo: Paulus, 2004.

Occam, Guillelmus de. Opera politica, v.1 \& 2. Organizado por R. F. Benett et al. Manchester: Manchester University Press, 1963.

Oribe, Beatriz Eugenia Reyes. La voluntad del fin em Tomás de Aquino. Buenos Aires: Vórtice, 2004.

Perot, L. Arnaldich. "Torre de Babel." In Gran Enciclopedia Rialp. Madrid: Rialp s/d.

Pinckaers, Servais Théodore. Las fuentes de la moral cristiana. Navarra: EUNSA, 2007.

Porro, Pasquale. Tomás de Aquino: perfil histórico-filosófico. São Paulo: Loyola, 2014.

Radbruch, Gustav. "Cinco minutos de filosofia do direito". Publicações da Advocacia Geral da União-AGU, 17 (2012): 261-263. Disponível em https://seer.agu.gov.br/index.php/EAGU/article/view/1620. Acesso em 18 jun. 2020. 
Ratzinger, Joseph. La teología de la historia de san Buenaventura. Madrid: Ediciones Encuentro, 2004. . Fé, Verdade, Tolerância. São Paulo: Ramon Llull, 2015.

Rawls, John. O liberalismo Político. São Paulo: WMF Martins Fontes, 2011. - Uma teoria da Justiça. São Paulo: Martins Fontes, 2011.

Reale, Giovanni e Dario Antiseri. Filosofia: Antiguidade e Idade Média, volume 1. São Paulo: Paulus, 2017.

Rops, Daniel. A Igreja das Catedrais e das Cruzadas, volume 3 de História da Igreja de Cristo. São Paulo: Quadrante, 2012.

Scherer, Daniel. A raiz anti-tomista da modernidade filosófica. Formosa, GO: Edições Santo Tomás, 2017.

Schindler, David C. Freedom From Reality: The Diabolical Character of Modern Liberty. Notre Dame: University of Notre Dame Press, 2017.

Schmitt, Carl. El Leviathan en la Teoría del Estado de Thomas Hobbes. Buenos Aires: Struhart \& Cía, 2002.

_. O nomos da Terra no direito das gentes do jus publicum europaeum. Rio de Janeiro: Contraponto: Ed. PUC-Rio, 2014.

Sieyès, Emmanuel Joseph. "Mémoire préliminaire à la Constitution, lu le 21 juillet 1789 : exposition des droits de l'homme et du citoyen par Sieyès". In Archives Parlementaires de 1787 à 1860 - Première série (17871799) Tome VIII - Du 5 mai 1789 an 15 septembre 1789. Paris : Librairie Administrative P. Dupont, 1875. Disponível em: https:// www.persee.fr/doc/arcpa_00000000_1875_num_8_1_6377_t2_0256_0000_6Fichier.pdf. Acesso em 13 jul. 2020.

- Qu'est-ce que le tiers état? Paris: Pagnerre, 1839.

Strauss, Leo. Direito Natural e História. São Paulo: Martins Fontes, 2014.

Streck, Lênio Luiz. "Professor de Harvard lança 'constitucionalismo Deus acima de todos"'. Consultor Jurídico, 23 abr. 2020. Disponível em: https://www.conjur.com.br/2020-abr-23/senso-incomum-professorharvard-lanca-constitucionalismo-deus-acima-todos. Acesso em 03 mai. 2020.

. "Eis porque abandonei o 'neoconstitucionalismo"'. Consultor Jurídico, 13 mar. 2014. Disponível em: https://www.conjur.com.br/2014-mar13/senso-incomum-eis-porque-abandonei-neoconstitucionalismo. Acesso em 15 mar. 2020. 
. "O pan-principiologismo e o sorriso do lagarto". Consultor Jurídico. São Paulo, 22 mar. 2012. Disponível em: https:// www.conjur.com.br/2012-mar-22/senso-incomum-panprincipiologismo-sorriso-lagarto. Acesso em 28 abr. 2020.

Tomás de Aquino. Do Reino e outros escritos. São Paulo: Armada, 2017.

Torres, Ricardo Lobo. Tratado de Direito Constitucional, Financeiro e Tributário: valores e princípios constitucionais tributários.

Tuck, Richard. Natural Rights Theories: Their Origin and Development. Cambridge: Cambridge University Press, 1981.

Vermeule, Adrian. "Beyond Originalism". The Atlantic, 31-03-2020: https://www.theatlantic.com/ideas/archive/2020/03/common-goodconstitutionalism/609037/ Acesso em 12 jul. 2020.

Villey, Michel. A formação do pensamento jurídico moderno. São Paulo: Martins Fontes, 2009.

Weber, Max. A Ética Protestante e o "Espirito" do Capitalismo. São Paulo: Companhia das Letras, 2018.

Xénophon. "Hieron ou Le Traité sur la Tyrannie". In Leo Strauss. De la Tyrannie. Paris: Gallimard, 1999. 
Natural Law and the Brazilian Constitutional Order:

The Origins of 'Neoconstitutionihilism' in Modern Natural Law

\begin{abstract}
This paper examines the relationship between Natural Law and the Brazilian constitutional order, marked by the prevalence of neo-constitutionalismo. Taking William of Ockham's doctrine as the starting point of Modern Natural Law, going through Hobbes's and Locke's thought, and arriving at Sieyes, we aim to show that neoconstitutionalism, far from constituting something new, is only a new stage in the development of these latter doctrines, which are at root nominalistic and antimetaphysical, and thus do not properly overcome Kelsen's positivism. This latter is also voluntaristic in its foundations. We conclude with a return to the Thomistic metaphysics of the intensive act of being as the foundation for a renewed juridical order.
\end{abstract}

KEYwORDS: Brazilian Constitution (1988); Natural Law; Constitutionalism (Neo); Criticism; Philosophy of Being. 